\title{
Consumo cultural do pensamento vasconceliano na literatura modernista brasileira: intercâmbios intelectuais na constituição do discurso da raça latino- americana na década de 1920
}

George Leonardo Seabra Coelho ${ }^{1}$

Resumo: O objetivo deste artigo é levantar discussões sobre os intercâmbios culturais entre alguns escritores modernistas brasileiros e José Vasconcelos na década de 1920. Nosso objetivo é destacar a visita do intelectual mexicano ao Brasil durante as comemorações do Centenário de Independência, em 1922, e como a comitiva mexicana deixou suas marcas em parte da intelectualidade brasileira. Para que possamos discutir esses intercâmbios, partiremos da noção de "consumo cultural" e de "outra produção" na obra La raza cósmica: misión de la raza ibero-americana (1925) de José Vasconcelos a partir da leitura de artigo de jornais escritos e de obras literárias de escritores modernistas do Brasil. No que concerne ao "consumo cultural" das teses vasconcelianas no Brasil, lançaremos mão de artigos de jornais escritos por Plínio Salgado e Cassiano Ricardo. Já no que se refere às obras literárias, veremos a possibilidade de uma "outra produção" das ideias elaboradas por José Vasconcelos no poema Toda a América (1926), de Ronald de Carvalho, e no poema Martim Cererê (1927), de Cassiano Ricardo. O artigo em questão se propõe a avaliar a influência do pensamento do mexicano José Vasconcelos em alguns intelectuais modernistas brasileiros, em particular o papel do mestiço e da mestiçagem como emblema da identidade nacional. Nesse sentido, nossa finalidade é demonstrar como ocorreram os intercâmbios entre intelectuais dos dois países bem como a forma com a qual as teses da Raça Cósmica vasconcelianas foram apropriadas pelos escritores brasileiros.

Palavras-chave: Raça; Literatura; Apropriação.

\footnotetext{
${ }^{1}$ Doutor em História. Atualmente é professor Adjunto da Universidade Federal do Tocantins (UFT), Brasil, onde desenvolve a pesquisa intitulada "Intercâmbios intelectuais latino-americanos coordenados pela Academia Brasileiro de Letras”. Endereço para correspondência: Rua 5 qd V casa 3 Setor Arnaldo Prieto, Arraias-TO, Cep: 77330-000. E-mail: george.coelho@ hotmail.com
}

\section{GANPHLAC}


Cultural consumption of the Vasconcellian echoes in Brazilian modernist literature: Intellectual exchanges in the constitution of Latin American race speech in the 1920's

\begin{abstract}
This article intends to raise discussions about the cultural exchanges among some Brazilian writers and José Vasconcelos in the 1920's. Our goal is to highlight the visit of the Mexican intellectual to Brazil during the celebrations of the Centennial of Independence in 1922, and how the Mexican delegation left its mark on part of the Brazilian intelligentsia. So that we can discuss these exchanges, we will start with the notion of "cultural consumption" and "other production" of the work La raza cósmica: misión de la raza ibero-americana (1925) by José Vasconcelos through reading articles from newspapers and literary works by Brazilian modernists writers. Regarding to "cultural consumption" from Vasconcelian thesis in Brazil, we are going to make use of newspaper articles which were written by Plínio Salgado and Cassiano Ricardo. On the other hand, regarding to the literary works, we are going to see the possibility of an "other production" from the ideas of José Vasconcelos in the poem Toda a América (1926) by Ronald de Carvalho and the poem Martim Cererê (1927) by Cassiano Ricardo. The article has as goal to evaluate the influence of José Vasconcelos thoughts in some Brazilian modernists, in special the role of the mestizo and miscegenation as a national identity emblem. This way, we intend to demonstrate how the exchanges between intellectuals of the two countries occurred and how the theses of the Vasconcelian Cosmic Race were appropriated by Brazilian writers.
\end{abstract}

Keywords: Race; Literature; Appropriation.

Artigo recebido em: 31/12/2017

Artigo aprovado em: 07/08/2018

\title{
Introdução
}

A segunda metade do século XIX foi marcada pelo processo de consolidação dos debates eugênicos no continente europeu. Olhando a partir de uma perspectiva mais ampla, o pensamento eugênico elaborado no velho continente anunciava a existência de

\section{GANPHLAC}

Revista Eletrônica da ANPHLAC, ISSN 1679-1061, №. 25, p. 183-221, Jul./Dez., 2018.

http://revista.anphlac.org.br 
raças "superiores" (puras) que deveriam triunfar e raças "inferiores" (mestiças) que deveriam ser dominadas. Essas questões também tiveram repercussão entre intelectuais latino-americanos, que, na maioria dos casos, produziram interpretações eugênicas bastante heterodoxas. No que se refere à miscigenação, Nancy Stepen (2005) sugere que enquanto as correntes anglo-saxônicas a entendiam como degeneração, os eugenistas latino-americanos não tardaram a desenvolver argumentos a seu favor, colocando-a como aprimoramento racial. Dois exemplos dessa reinterpretação são: a ideia da "raça cósmica" desenvolvida no México por José Vasconcelos e a teoria do “embranquecimento" elaborada no Brasil.

No que se refere ao México, Laura Suárez y López Guazo (2005) destaca que diversos intelectuais daquele país passaram a refutar as teses dos eugenistas europeus, entre eles o escritor, político e educador José Vasconcelos ${ }^{2}$. Apesar de vários intelectuais mexicanos abordarem a questão da mestiçagem, Alexandra Stern (2000) ressalta que José Vasconcelos propôs uma "reinterpretación radical de aquellas doctrinas de 'razas' puras que habian dejado atrapados a los positivistas dentro de la imaginación racial de las teorías europeas" (p. 62). Maurício Tenório (1994) e Leonardo de Carvalho (2016) concordam com as autoras e acrescentam outro ponto; a despeito de reinterpretar as doutrinas raciais, Vasconcelos não se afasta do conceito europeu ${ }^{3}$ de raça na composição de sua teoria da "raça cósmica", mas o redefine. De acordo com essa visão, Vasconcelos propõe uma inversão conceitual do racismo eugênico europeu na qual pureza racial seria exemplo de fraqueza e mistura racial representaria a superioridade.

Os dilemas eugênicos também foram representativos entre a intelectualidade brasileira. Lilia Schwarcz (1993) salienta que as teorias raciais europeias receberam uma entusiasmada acolhida no Brasil, mas essa receptividade não significou que tenham

\footnotetext{
${ }^{2}$ José Vasconcelos difere da visão racial defendida por intelectuais mexicanos do século XIX, como Francisco Pimentel, Alfredo Chavero ou Vicente Riva Palacio, assim como da concepção de mestiçagem defendida por Andrés Molina Enríquez e Manuel Gamio no início do século XX.

${ }^{3}$ Mesmo estando consciente da questão da eugenia, podemos refutar a afirmação de que o intelectual mexicano formulasse propostas eugênicas. Por um lado, esse campo de saber implicava envolvimento com a medicina, a biologia e a antropologia física, os quais eram mais ou menos desprezados por Vasconcelos. Por outro lado, é certo dizer que Vasconcelos estava mais preocupado com a dimensão espiritual e cultural da miscigenação do que com questões cientificistas. Por essas duas razões podemos dizer que a eugenia vasconceliana organizou-se a partir de duas óticas: uma que entrelaçava o jogo entre a herança biológica, o projeto de nação mexicana e a constituição de uma identidade ibero-americana; e outra que partia da harmonia advinda da mistura racial, das diversidades étnicas e das várias culturas americanas.
}

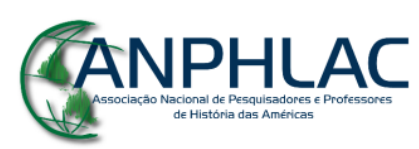


permanecido tal qual eram discutidas no continente europeu. A autora acentua ainda que nessa negociação, os intelectuais brasileiros atualizaram o que combinava e descartaram "o que de certa forma era problemático para a construção de um argumento racial" coerente com a sociedade brasileira (SCHWARCZ, 1993, p. 19). Para a autora, essas ideias foram produzidas em diferentes estabelecimentos de ensino e pesquisa, incluindo: Museus Etnográficos Brasileiros, Institutos Históricos e Geográficos, Faculdades de Direito e Faculdades de Medicina. A autora destaca que as diversas teorias saídas desses centros de ensino e pesquisa produziram uma interpretação social sobre a raça, a qual foi útil aos interesses dos grupos que se apropriavam delas.

Com base nessas considerações iniciais, o presente artigo contribuirá com o esforço realizado por esses autores e autoras. Nosso intuito aqui é apresentar o campo literário modernista brasileiro como outro espaço de "consumo cultural" das teorias raciais. Para essa caracterização, discutiremos como Ronald de Carvalho, Plínio Salgado e Cassiano Ricardo apropriaram-se dos enunciados eugênicos compostos por José Vasconcelos. A partir dessa chave interpretativa, trataremos dos intercâmbios culturais entre Brasil e México e como o "tema racial" foi posto pelos modernistas brasileiros em diálogo com o ensaísta mexicano. Para tanto, debateremos os desdobramentos da visita de José Vasconcelos ao Brasil em 1922 e o "consumo cultural" da tese da "raça cósmica" por esses três escritores locais. Para que seja possível desenvolver tal diálogo, organizamos nossa pesquisa em dois níveis: em um ângulo mais ampliado, daremos ênfase à repercussão da viagem de José Vasconcelos ao Brasil a partir dos periódicos; e em um ângulo mais vertical, nos debruçaremos nas condições em que raça e miscigenação foram articuladas nos textos literários escritos pelos três modernistas brasileiros.

$\mathrm{Na}$ primeira seção - Passagem de José Vasconcelos no Centenário da Independência Brasileira -, apresentaremos um breve relato da visita do intelectual mexicano ao Brasil em 1922, o qual será elaborado segundo as notícias veiculadas pelos periódicos brasileiros. No que se refere à atuação desse intelectual nas festividades do I Centenário da Independência, Regina Crespo (2003) acha por bem afirmar que a participação da comitiva mexicana nessa celebração inaugurou uma nova etapa de contatos entre intelectuais dos dois países. Também é certo considerar a escrita do livro La raza cósmica (1925), de José Vasconcelos, como produto dessa missão diplomática,

\section{GANPHLAC}


mas não podemos menosprezar dois pontos importantes referentes à composição da obra: ela surge respondendo a um debate bastante mexicano e, ao mesmo tempo, os temas e as ideias presentes neste ensaio já estavam em ampla circulação na América Latina antes de sua escrita. A partir dessas primeiras ponderações sobre a visita de José Vasconcelos ao Brasil e a influência dessa viagem na escrita deste ensaio, discutiremos o "consumo cultural" dessa obra por parte da intelectualidade brasileira na década de 1920.

Após abordar a participação do intelectual mexicano durante os festejos do I Centenário, veremos na segunda seção - Apropriações das teses de José Vasconcelos pela intelectualidade brasileira - a repercussão dessa visita entre uma fração dos escritores locais. Para debatermos tal efeito, destacaremos como a viagem de Ronald de Carvalho ao México em 1925 deixou marcas profundas na escrita do poema Toda a América. Ainda nesse tópico, abordaremos como o "consumo cultural" da tese da "raça cósmica" vasconceliana também marcou o movimento literário organizado por Plínio Salgado e Cassiano Ricardo. Para pontuar essas influências, lançaremos mão da leitura de artigos de jornais escritos por esses verde-amarelistas bem como a maneira com a qual alguns enunciados vasconcelianos estão presentes no manifesto "Nheengaçu verdeamarelo". As análises presentes nesse tópico serão importantes para fortalecer nossa argumentação desenvolvida na seção seguinte: os "consumos culturais" da tese da "raça cósmica" na composição do poema Martim Cererê de Cassiano Ricardo.

Os intercâmbios culturais presentes no poema de Cassiano Ricardo serão examinados na terceira e última seção deste artigo: Consumo cultural e outra produção de La raza Cósmica no poema Martim Cererê. Entendemos que a partir do estudo do poema de Cassiano Ricardo, podemos enfatizar suas interfaces com a obra ensaística de José Vasconcelos e, concomitantemente, perceber as trocas literárias entre o poeta brasileiro e o conjunto de ideias vasconcelianas. Veremos que tais trocas literárias tinham um objetivo bastante específico: idealizar a suposta harmonia racial brasileira e conferir uma missão universal para o Brasil. Acreditamos que essa criação poética é um exemplo das formas como o ideal de brasilidade dessa fração modernista sofreu forte influência da tese da "raça cósmica" defendida pelo intelectual mexicano.

Como será abordado ao longo deste artigo, entendemos que o "consumo cultural" de um texto é tomado como produção de representações não idênticas às que o

\section{GANPHLAC}


produtor ou o autor investiram na obra. Fundamentado na perspectiva de "consumo cultural" de um texto, Roger Chartier (1990) propõe a noção de "outra produção". Conforme tal princípio conceitual, o historiador constrói as bases para a noção de apropriação, a qual será útil para compreendermos os usos e as interpretações dos produtos culturais elaborados por escritores latino-americanos na década de 1920. Suas contribuições nos auxiliaram no entendimento das formas como os textos foram apreendidos e/ou manipulados pelos grupos sociais. Com base nesse arcabouço conceitual, veremos como as teses encontradas no ensaio La raza cósmica de José Vasconcelos foram apropriadas por Ronald de Carvalho, Plínio Salgado e Cassiano Ricardo em suas produções literárias. Seguindo essa perspectiva, concordamos com Chartier ao afirmar que a significação dos textos depende das capacidades, dos códigos e das convenções de leitura das diferentes comunidades e diferentes públicos, assim como das "variações entre a significação, a interpretação e as apropriações plurais que sempre inventam, deslocam, subvertem" os significados (CHARTIER, 2002, p. 259).

A partir da problematização proposta aqui, lançaremos uma luz sob as diversas relações entre os autores - José Vasconcelos, Ronald de Carvalho, Plínio Salgado e Cassiano Ricardo -, as obras - La Raza Cósmica, Toda a América e Martim Cererê - e o público - a intelectualidade modernista brasileira. Dessa forma, baseados na noção de “consumo cultural" e de "outra produção" elaborada por Roger Chartier, convidamos o leitor a nos acompanhar ao longo da investigação dos limites e alcances da tese da "raça cósmica" entre parte dos escritores modernistas brasileiros da segunda metade da década de 1920.

\section{Passagem de José Vasconcelos no Centenário da Independência Brasileira}

Para entender o porquê de José Vasconcelos ter sido nomeado para chefiar a missão diplomática nas Comemorações do I Centenário da Independência do Brasil, torna-se importante recorrer ao cenário mexicano no período posterior à Revolução de 1910. Nesse contexto, Claude Fell (2009) ressalta que a elite intelectual mexicana passou a tomar consciência de seus diversos problemas internos. Segundo o autor, José Vasconcelos pertence à geração que depositava toda sua fé na ideia de que "la educación podía ser un instrumento formidable para desestratificar y reequilibrar la sociedad" (FELL, 2009, p. 10). Além da importância da educação, Vasconcelos também

\section{GANPHLAC}


pertencia a uma corrente de pensamento que colocava toda sua confiança no papel social dos intelectuais bem como no caráter transformador da cultura. Essas ideias eram compartilhadas em um grupo reunido em torno do Ateneo de la Juventud ${ }^{4}$, muitos dos quais acompanhariam José Vasconcelos em sua campanha pela instrução pública durante os anos de 1921 e 1924.

Após a época revolucionária, Vasconcelos foi Reitor da Universidade Nacional do México em 1920 e participou da criação da Secretaria de Educação Pública (SEP), órgão que dirigiu entre 1921 e 1924. A atuação de Vasconcelos no governo de Álvaro Obregón foi marcada pela extensa campanha de educação em povoados, comunidades indígenas, associações de camponeses e trabalhadores. Além de estar à frente da criação e ser o primeiro diretor da SEP, o intelectual mexicano também compôs diversas missões diplomáticas pelo continente americano. É consenso que durante essas missões, Vasconcelos defendeu o intercâmbio latino-americano, assim como buscou abrir espaço para a inserção mais visível do México no continente.

É unanime entre os estudiosos da trajetória de Vasconcelos que entre 1920 e 1924, o intelectual viveu os anos mais célebres de sua carreira política. De acordo com Claude Fell (2009), "es uno de los escasos ejemplos [...] del 'filósofo', del intelectual latinoamericano a quien se confiere la enorme responsabilidad de dotar a su país de un sistema educativo" (p. 12). Para o estudioso, "Vasconcelos se cuenta entre los primeros que, em Latinoamérica, luchan y actúan para instaurar una cultura a la vez nacional, continental y popular" (p. 14). Fell compreende esses anos como um momento único na trajetória de Vasconcelos, pois foi naquela época que o intelectual pôde associar de modo direto "pensamiento y ación". No entanto, após 1925, solidificou-se - na sociedade mexicana - a imagem de um "hombre amargo e al margem" devido ao seu afastamento da "cosa pública" (FELL, 2009, p. 11). Apesar do aparente enfraquecimento político nos anos subsequentes à sua saída do debate público, o instante áureo da trajetória do ensaísta mexicano é fundamental para compreender o motivo de sua escolha como representante na missão diplomática que percorreu alguns países do Cone Sul em 1922.

\footnotetext{
${ }^{4}$ Esse grupo foi fundado por José Vasconcelos em 1909, sendo presidente da instituição em 1912. Esse grupo de intelectuais reuniu escritores como Pedro Henríquez Ureña e Alfonso Reyes Ochoa, o filósofo Antonio Caso e o pintor Diego Rivera.
}

\section{GANPHLAC}


No que diz respeito à atuação diplomática, Maurício Tenório (1994) entende que a designação de José Vasconcelos como embaixador especial na missão diplomática ao Cone Sul deveu-se a dois motivos: "pela vontade manifesta do agraciado" e "pelo prestígio que Vasconcelos tinha entre as elites intelectuais latino-americanas" (p. 128). Para Tenório, o presidente mexicano Alvaró Obregón “sabia da fama de Vasconcelos e, por isso mesmo, o enviou não apenas ao Brasil, mas também ao Uruguai, à Argentina, ao Chile e a Washington" (p. 128). Regina Crespo (2003) reforça a posição de que a missão de Vasconcelos era divulgar as conquistas do "novo país que se estava construindo e cujos resultados, poderiam, numa espécie de 'política cultural de exportação' aos países latino-americanos, chegar até a unificá-los sob a liderança mexicana" (p. 194). Claude Fell (2009) também corrobora com a visão de que o objetivo da missão diplomática de Vasconcelos era duplo: estreitar os vínculos econômicos e divulgar a realidade sociopolítica e cultural do México. A partir dessas três interpretações, podemos acentuar que a escolha de José Vasconcelos como embaixador especial na missão mexicana ao Cone-Sul, em 1922, deu-se por três motivos: a respeitabilidade conferida ao intelectual entre a comunidade latinoamericana, a necessidade de construir uma nova imagem do México revolucionário e para demarcar o espaço do México entre outras Repúblicas ibero-americanas.

Diversos órgãos da imprensa brasileira noticiam o embarque, a chegada e a estadia da comitiva ${ }^{5}$ mexicana no Brasil. Entre as diversas atividades oficiais a serem cumpridas durante as comemorações do I Centenário da Independência, Vasconcelos foi o orador na entrega da estátua de Cuauhtémoc ao povo brasileiro, concedeu entrevistas em redações de jornais, visitou instalações militares, discursou na Academia Brasileira de Letras (ABL) e viajou para outros estados, como, por exemplo, São Paulo, Bahia e Minas Gerais. Em todas essas ocasiões, o embaixador especial aproveitou para divulgar as transformações que a Revolução de 1910 havia realizado no México. Após cumprir a agenda oficial, os periódicos informam sobre a partida de Vasconcelos e sua comitiva para o Uruguai, Argentina e Chile, e seu retorno ao Brasil apenas para embarcar no navio Pan-American rumo a México.

\footnotetext{
${ }^{5}$ A comitiva mexicana era composta pelo Gal. Manuel Pérez Treviño - chefe do Estado-Maior mexicano -, pelos diplomatas Pablo Campos Ortiz e Alfonso de Rozenweig, pelos pintores Robert Montenegro e Gabriel Fernández Lesma, pelos poetas Carlos Pellicer e Julio Torri e o crítico literário dominicano Pedro Henríquez Ureña.
}

\section{CANPHLAC}

Revista Eletrônica da ANPHLAC, ISSN 1679-1061, №. 25, p. 183-221, Jul./Dez., 2018.

http://revista.anphlac.org.br 
Entre as diversas atividades noticiadas pela imprensa, as duas conferências realizadas na $\mathrm{ABL}$ ganharam amplo destaque nos periódicos. A primeira das duas conferências intitula-se "El problema do México", segundo a imprensa local, seu tema versou sobre "a evolução histórica de seu país e a nova etapa da História do México" (O JORNAL, 25 de agosto de 1922, p. 1). Para expor essa "nova fase de prosperidade", José Vasconcelos descreveu o "surto novo" da "política interna e externa, com demonstrações positivas de inteligência e capacidade" do povo mexicano. Os periódicos descrevem o sumário completo dos temas explanados nessa conferência, na qual o intelectual mexicano expôs sua concepção de "latino-americanismo e a necessidade de que [o americano] se torne autóctone, deixando de copiar servilmente os fortes, como tem sido feito até agora [bem como,] a raça como fator de unidade superior ao nacionalismo político" (O PAÍZ, 26 de agosto de 1922, p. 6). A segunda conferência, realizada nos salões da ABL, intitula-se "La educación pública en México", novamente os jornais trazem seu sumário, no qual o intelectual retoma a questão da miscigenação. Os noticiários também destacam que essa segunda conferência tratou da "tendência popular da educação e o propósito de criar a consciência étnica, ou seja, o sentimento de raça acima do sentimento pátrio" (O PAÍZ, 3 de setembro de 1922, p. 4).

É importante frisar que todas as conferências pronunciadas pelo embaixador especial se tornaram prelúdios do ensaio La raza cósmica. Em outras palavras, a necessidade de intercâmbio entre as nações latino-americanas, a superioridade da etnia sobre o político e a valorização da cultura americana, serão posteriormente tratadas de forma mais sistematizadas em sua obra que fundamenta a tese da "raça cósmica". Para compreendermos mais a fundo as interfaces entre os pronunciamentos de José Vasconcelos durante a visita ao Brasil e a escrita do La raza cósmica ${ }_{2}$ é importante fazermos algumas considerações.

Maurício Tenório (1994) considera que José Vasconcelos cumpriu em sua estadia no Brasil a tarefa oficial de fazer propaganda de seu país, já como filósofo, colheu elementos para a formulação de seu pensamento ibero-americano. Para o autor, a missão mexicana deixou no Rio um Cuauhtémoc carioca, um pavilhão neocolonial e diversas peças artísticas, por outro lado, "Vasconcelos partiu levando uma bagagem de mitos [...] brasileiros em reforço a sua ideia de uma raça ibérica superior” (p. 124). O autor juntamente a Regina Crespo (2003) são unânimes em afirmar que o Brasil deixou

\section{GANPHLAC}


suas marcas no intelectual, pois sua visita lhe abriu novas perspectivas, que serão fundidas posteriormente. Foi naquele Brasil idílico que Vasconcelos vislumbrou o berço de uma nova civilização, a qual poderia ser expandida para todo o conjunto da América Latina.

É justo considerar que a sucessão de eventos oficiais durante as comemorações do I Centenário serviram para que o intelectual se munisse de elementos para construir sua utopia, mas é importante outras ressalvas. Uma delas é posta por João G. Ascenso (2013), crítico que destaca que José Vasconcelos realiza uma reinvenção das teses oitocentistas de raça ao propor

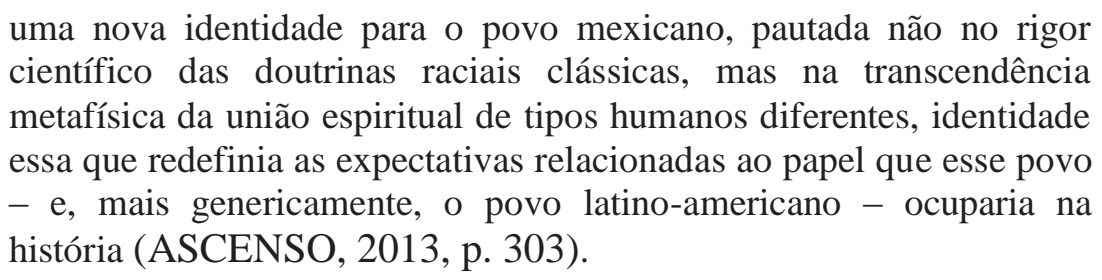

Como visto a partir dessa análise, este ensaio pretendia responder um tema que já havia ganhado espaço entre a intelectualidade mexicana, antes mesmo de elencar o Brasil como berço dessa nova humanidade. Salvo tal ponderação, o autor não nega que a visita ao Brasil ofereceu argumentos para que encontrasse uma saída para o dilema mexicano através de especulações filosóficas, as quais não ficariam restritas apenas à sua nação, mas seriam emprestadas para todos os países latino-americanos.

Independentemente da forte influência que a visita ao Brasil exerceu na produção desse ensaio, Claude Fell (2009) nos alerta que antes de 1922, o Brasil aparece apenas em referências circunstanciais nos escritos vasconcelianos. Para o crítico, somente após sua saída da SEP, em 1925, é que o intelectual revisa e organiza as notas da viagem realizada em 1922, reunidas com alguns artigos publicados na imprensa dos países visitados no volume La raza cósmica. Apesar dessa posição crítica, o autor se mantém preso à interpretação de que a obra pode ser interpretada de duas formas: o resultado do encantamento pelo Brasil e a idealização do devir iberoamericano. Esse encantamento e essa expectativa do devir latino-americana são negociados em uma mescla entre história e lenda, na qual o intelectual mexicano buscou compor um "programa espiritual" destinado "a consolidar definitivamente la cohesión del continente ibero-americano y a hacer de él la cuna de la humanidade nueva" (p.

\section{CANPHLAC}

Revista Eletrônica da ANPHLAC, ISSN 1679-1061, №. 25, p. 183-221, Jul./Dez., 2018.

http://revista.anphlac.org.br 
639). Em síntese, Fell defende que o livro é uma mistura de manifesto e encantamento que fundidos expressam

\begin{abstract}
uma tentativa - no exenta de contradiciones y a veces de incoherencias - de proporcionar la sínteses intuitiva de uma nueva ideología Movilizadora. Gira alrededor de la noción confusa de "raza", que, em la mente de Vasconcelos, es uma amalgama de los conceptos de "cultura", "civilización", "Pueblo", "costumbres", "lengua” (FELL, 2009, p. 639).
\end{abstract}

Para Fell, a representação idílica do Brasil foi construída a partir da unificação da "belleza de sus paisajes" e do "esplendor de su naturaleza" com "la mezcla armoniosa de las distintas etnias" (p. 601). O autor ressalta que o ensaísta idealiza o Brasil como uma "gran civilización que no se há fundado em la conquista y la sangue sino em la fraternidad, el trabajo y la luz" (FELL, 2009, p. 641). Na construção da imagem idílica do Brasil, as paisagens eram perfeitas, não existia miséria, o povo era amável e o governo era composto de homens cultos e de espírito democrático. O autor defende que toda essa construção ideológica pretendia servir para "excitar la imaginación y suscitar el entusiasmo de los iberoamericanistas" (p. 641). De modo genérico, o objetivo principal do ensaio é defender a miscigenação e o surgimento da "quinta raça" como parte de um projeto racial ibero-americano, ou seja, o ensaísta fundamentou sua teoria utópica da nova raça que se formaria na América Latina, tendo o Brasil como a expressão mais imediata.

Ao realizarmos a leitura do ensaio, vemos como essa teoria da síntese feliz entre as raças foi organizada pelo intelectual mexicano. No prefácio, Vasconcelos anuncia que: "Es tesis central del presente libro que las distintas razas del mundo tienden a mezclarse cada vez más, hasta formar un nuevo tipo humano, compuesto con la selección de cada uno de los pueblos" (VASCONCELOS, 1948, p. 9). Defendendo a tese de que a humanidade caminha para a fusão entre as diferentes raças, o ensaísta argumenta que a "quinta raza" chegará ao planeta portando "los triunfos de la primera cultura verdaderamente universal, verdaderamente cósmica" (p. 53-54). Após o prefácio, a obra foi estruturada da seguinte forma: na primeira parte, denominada " $E l$ mestizaje", o ensaísta desenvolveu os principais elementos de sua teoria; já na segunda parte - "Notas de viaje" -, lemos as observações a respeito das viagens feitas ao Brasil. Nessa segunda parte, José Vasconcelos organiza seu texto destacando algumas cidades

\title{
GANPHLAC
}

Revista Eletrônica da ANPHLAC, ISSN 1679-1061, №. 25, p. 183-221, Jul./Dez., 2018.

http://revista.anphlac.org.br 
que conheceu: Rio de Janeiro, Santos, Belo Horizonte e Juiz de Fora. Além de descrever sua passagem por essas localidades, o intelectual narra diversas situações ocorridas durante sua missão oficial. Nas próximas duas seções, veremos o impacto dessa obra entre parte da intelectualidade modernista brasileira na segunda metade da década de 1920, o qual será analisado a partir de suas produções literárias.

Além das comemorações do I Centenário da Independência, não podemos nos esquecer de que o ano de 1922 foi um importante divisor de águas na vida cultural brasileira. Entre os importantes acontecimentos desenrolados naquele ano, podemos citar a Semana de Arte Moderna. Esse evento marca o momento em que diversos escritores buscavam redefinir a linguagem literária e cultural do país, atitude que ficou conhecida com o nome genérico de modernismo. Frente a essa tomada de consciência nacional, consideramos que a passagem do intelectual mexicano e a publicação de $L a$ raza cósmica também marcou alguns escritores modernistas ao longo da década de 1920. Considerando tal constatação, veremos no próximo tópico como ocorreu o intercâmbio cultural entre as teses de José Vasconcelos e alguns escritores brasileiros ligados ao modernismo, mais especificamente, entre Ronald de Carvalho, Plínio Salgado e Cassiano Ricardo.

\section{Apropriações das teses de José Vasconcelos pela intelectualidade brasileira}

Ao analisar o "consumo cultural" da obra La raza cósmica por escritores modernistas brasileiros na década de 1920, não podemos menosprezar o peso que o "tema racial" tinha para eles. Para que possamos entender a relevância da questão racial nesses intercâmbios, torna-se necessário discutir o impacto das teorias eugênicas entre a intelectualidade latino-americana naqueles anos. Sobre essa questão, os apontamentos de Nancy Stepan (2005) e Lilia Schawarcz (2012) são importantes para desfazer duas impressões: que foi José Vasconcelos quem inventou a positividade da mescla racial e que a entrada dessa reflexão no Brasil se dá apenas pelo intelectual mexicano. Ao desconstruir essa imagem, não negamos a importância de José Vasconcelos para o diálogo racial no Brasil da década de 1902, mas pontuaremos esse debate na produção de alguns textos modernistas locais.

Ao explorar a inserção dos debates eugênicos no Brasil e no México, Nancy Stepan (2005) ressalta que os resultados dessas discussões se adequaram às diferentes

\section{GANPHLAC}


tradições do pensamento científico, político e cultural desses países. Para a autora, a despeito de articularem de maneiras diversas, essas correntes eugenistas estavam unidas por um ponto comum: a construção da nacionalidade em países mestiços. No caso específico do Brasil, o discurso eugênico ${ }^{6}$ que subsidiava os debates sobre raça e identidade nacional floresceu em resposta às contingências do nacionalismo e às discussões acerca das políticas de imigração no período pós-abolicionista. Ao tratar desse assunto, Lilia Schwarcz (2012) defende que as teses eugenistas oscilaram entre versões negativas e positivas. Na vertente negativa, a mestiçagem parecia atestar a falência da nação, já na vertente positiva, a mestiçagem nem sempre levaria à degeneração. Segundo a autora, o casamento entre evolucionismo e darwinismo social possibilitou aos eugenistas brasileiros apostarem na miscigenação positiva, contando que o resultado fosse branco. Devido a essa ressignificação, em vez de mácula, a mestiçagem se transformou em "promessa" e até "fortuna".

Levando em consideração o predomínio das teorias do branqueamento nos primeiros anos do século XX, defendemos que no decorrer da segunda década desse século algumas apropriações das teses vasconcelianas produziram outro resultado. Frente a essa constatação, avaliamos que o "consumo cultural" da tese da "raça cósmica" realizada pelos modernistas Ronald de Carvalho, Plínio Salgado e Cassiano Ricardo apresentaram outra saída para o dilema racial brasileiro: a mestiçagem como fator positivo independentemente da cor, e mais, foi elevada ao status de definidora da brasilidade. Analisaremos, nesta seção, como o pensamento elaborado por José Vasconcelos foi apropriado por esses escritores na composição de uma ideia de brasilidade ligada à mestiçagem.

Antes da chegada da missão mexicana ao Brasil, a imprensa nacional já apontava José Vasconcelos como um indivíduo de "inteligência poderosa, um filósofo amável e um estadista glorioso" (A NOITE, 19 de agosto de 1922, p. 6). Após seu retorno ao México, os elogios dirigidos ao intelectual mexicano permaneceram de forma prodigiosa. Em um longo artigo de Sylvio de Brito, deparamo-nos com diversos elogios à atuação de José Vasconcelos à frente do SEP do México. Para Sylvio de Brito, José Vasconcelos é um jovem com clarividência política e de "sólida cultura" e, por isso, foi

\footnotetext{
${ }^{6}$ Os expoentes do debate eugênico no Brasil eram: Nina Rodrigues (professor da Faculdade de Medicina da Bahia), Renato Khel (professor da Faculdade de Medicina do Rio de Janeiro) e Edgar Roquete-Pinto (antropólogo e Presidente do I Congresso Brasileiro de Eugenia.
}

\section{CANPHLAC}

Revista Eletrônica da ANPHLAC, ISSN 1679-1061, №. 25, p. 183-221, Jul./Dez., 2018.

http://revista.anphlac.org.br 
"indicado para a missão de intérprete, de orientador e de realizador da nova política" mexicana. O comentarista finaliza seu artigo afirmando que "José Vasconcelos, é incontestavelmente [...] um dos mais expressivos vultos americanos" (O JORNAL, 11 de abril de 1923, p. 4). Em uma manchete, José Vasconcelos é posto como um "impressionante pensador e patriótico" que gozava no Brasil "do maior prestígio, como uma das mais poderosas mentalidades da América" (JORNAL DO BRASIL, 15 de dezembro de 1925 , p. 6).

Esses exemplos nos revelam que o intelectual mexicano adquiriu uma grande respeitabilidade entre os brasileiros. Essa fama pode ser explicada pelo fato de que o intelectual mexicano sintetizou os anseios de uma América Latina que se queria moderna e, como veremos, emprestou esse ideal aos escritores modernistas para a construção de uma brasilidade mestiça. Além das palavras elogiosas ao intelectual mexicano, os intercâmbios entre os dois países nos anos posteriores ao I Centenário de Independência se intensificaram. Outros exemplos que fortalecem o intercâmbio intelectual são as visitas de diversas personalidades brasileiras ao México a partir de 1923. Um primeiro intelectual de destaque que visitou aquele país, a convite de José Vasconcelos, foi o modernista e diplomata Ronald de Carvalho. Para entender a escolha desse escritor como representante diplomático brasileiro em visita ao México, é importante por em evidência sua trajetória.

Em 1914, o escritor carioca ingressou na carreira diplomática trabalhando para a Secretaria do Ministério das Relações Exteriores. No espaço de dez anos, depois de ter servido na França e na Holanda, alcançaria o posto de Ministro Plenipotenciário de segunda classe ${ }^{7}$. A partir de 1923, dirigiu, no Itamarati, o Departamento de Negócios Políticos e Diplomáticos da Europa, foi em seguida o primeiro-secretário da embaixada especial no Peru e obteve, em 1924, sua promoção ao cargo de primeiro-oficial.

No campo literário, Ronald de Carvalho foi denominado de "príncipe dos prosadores brasileiros" por Coelho Neto. Também foi ponte de ligação entre as vanguardas portuguesa e brasileira a partir da revista Orpheu na década de 1910. Foi autor de umas das mais famosas obras de crítica literária das primeiras décadas do

\footnotetext{
${ }^{7}$ No que se refere ao ingresso de Ronald de Carvalho na diplomacia, Ricardo de Carvalho (2006, p. 75) considera que tal escolha de carreira refletia uma tradição iniciada no século XIX e que prosseguiria no século XX, ou seja, a de "homens de letras que buscavam a diplomacia não apenas como uma forma de inserção social e econômica, mas também como oportunidade de viajar para o Exterior".
}

\section{GANPHLAC}


século XX: Pequena História da Literatura Brasileira (1919). Para Luciana StegagnoPicchio (2004), Ronald de Carvalho pertenceu à "Poesia de Penumbra", se bem que a autora o inclua entre os modernistas cariocas. Em relação à sua passagem para o Modernismo, a autora destaca que o caminho se deu após o exórdio parnasiano, que chega ao fim em 1921 com seu livro Epigramas irônicos e sentimentais. Ainda sobre sua adesão ao modernismo, a autora considera que essa passagem se efetivou mais por maturação do que por fratura estética. A parir de 1922 torna-se um modernista convicto, chegado a participar da Semana de Arte Moderna com a conferência intitulada "A pintura e a escultura moderna no Brasil" e com a leitura do poema "Os sapos" de Manoel Bandeira.

André Botelho (2005) e Ricardo de Carvalho (2006) consideram que a viagem diplomática de Ronald de Carvalho ao México foi um importante marco nas relações políticas e intelectuais entre os dois países. Essa afirmação é válida se considerarmos que Ronald de Carvalho não vai ao México apenas como um turista a convite de Vasconcelos, mas sim como uma personalidade responsável por representar a intelectualidade e o Estado brasileiro. Como resultado pessoal dessa viagem diplomática, Ronald de Carvalho pôde reunir elementos que serviram de matéria-prima para escrever seu poema Toda a América ${ }^{8}$ (1926).

A repercussão da viagem de Ronald de Carvalho e a publicação desse poema podem ser vistos na imprensa brasileira. A título de exemplo, podemos lançar mão de um artigo assinado de João de Barros no qual o crítico exalta o pensamento do intelectual mexicano exposto em seu ensaio La raza Cósmica, vejamos:

ninguém, que tenha visto e conhecido o Brasil e as suas formidáveis capacidades de inteligência, de ação e de riqueza, poderá negar ou não pressentir o destino hegemônico que lhe está marcado pelas inelutáveis leis da evolução histórica. Aí se está elaborando e formulando a nova consciência da América e do Mundo (A NOITE, 4 de junho de 1926, p. 1).

Após destacar o "destino hegemônico" que o Brasil alcançou dentro do projeto vasconceliano, João de Barros traz à discussão o poema recém lançado de Ronald de Carvalho. Para o comentarista, o poema faz pensar "que já chegou a hora radiosa do

\footnotetext{
${ }^{8}$ A impressão desse livro deu-se em 15 de dezembro de 1925 com ilustrações feitas por Nicola De Garo baseados em motivos Incas, Maias e Astecas.
}

\section{CANPHLAC}

Revista Eletrônica da ANPHLAC, ISSN 1679-1061, №. 25, p. 183-221, Jul./Dez., 2018.

http://revista.anphlac.org.br 
alvorecer dessa [nova] consciência". João de Barros não hesita em demarcar diversos paralelos entre esse poema e o ensaio do intelectual mexicano. Ao lermos o livro Toda a América, fica evidente o paralelo apontado pelo comentarista, mas antes de uma análise mais profunda de tal "consumo cultural", tornam-se oportunas algumas considerações sobre as experiências modernistas no Brasil.

Jerusa Ferreira (1970) lembra que o Modernismo brasileiro foi uma reação ao Parnasianismo e ao Simbolismo, reação esta que possibilitou buscar a originalidade em vários setores da vida cultural, particularmente na busca por um ideal de brasilidade. Conforme argumenta Mônica P. Velloso (2010), concordamos que na edificação dessa brasilidade houve a valorização dos dialetos, dos costumes e do sertanejo em contraposição à cultura europeia. Para a autora, a constituição da brasilidade modernista derivou da articulação entre o antigo e o moderno, de forma que o resgate da tradição se realizava em nome do Brasil contemporâneo.

Eduardo Jardim (1978) nos apresenta outro horizonte de interpretação sobre a brasilidade modernista. Para esse estudioso, fica clara a necessidade modernista de formar a unidade pela busca da brasilidade. Segundo o autor, as produções modernistas estavam diretamente ligadas à reflexão filosófica elaborada por Graça Aranha em sua obra A estética da vida (1921). A análise do autor se opôs às duas versões predominantes até a década de 1970: uma que retrata a brasilidade como resultado da preocupação iniciada pelas vanguardas europeias com o primitivismo; outra que relaciona as propostas modernistas com os acontecimentos político-sociais brasileiro. Embora não negasse essas duas influências, o autor coloca em pauta dois caminhos abertos por Graça Aranha: o apelo à "intuição" para se chegar à nacionalidade, de um lado, e a "integração" como base para a formação de uma cultura nacional, de outro.

Sem embargo das diferentes propostas e grupos modernistas vigentes na década de 1920, Ronald de Carvalho, Plínio Salgado e Cassiano Ricardo buscavam uma estética que representasse a nacionalidade. Apesar da especificidade de cada escritor, todos possuíam motivos estéticos bastante próximos: a exaltação da natureza brasileira e da mestiçagem como caminho para a construção de uma ideia de brasilidade. Mesmo que o primeiro escritor pertencesse ao grupo carioca e os dois últimos ligados ao grupo paulista, acreditamos que esses intelectuais se apropriaram das teses vasconcelianas, principalmente dos enunciados da valorização da miscigenação e do devir inerente às

\section{GANPHLAC}


nações latino-americanas de diferentes formas. Com base nessa compreensão sobre o modernismo brasileiro, consideramos que algumas obras desses modernistas buscavam a constituição da brasilidade a partir do "consumo cultural" do ensaio La raza cósmica.

A leitura do poema Toda a América de Ronald de Carvalho nos apresenta essa possibilidade estética do Modernismo Brasileiro, ou seja, a miscigenação como característica intrínseca das nações latino-americanas e, consecutivamente, do Brasil. Logo no texto introdutório do poema - intitulado "Advertência" - vemos como o autor se inspira nas teses defendidas por José Vasconcelos. Vejamos: "Europeu! filho da obediência, da economia e do bom-senso,/tu não sabes o que é ser Americano![...] Nessa maré de massas informes, onde as raças e as línguas/se dissolvem" (CARVALHO, 1926, p. 13-15). Ao poetizar a incapacidade do europeu em entender a América - local em que "as raças e as línguas se dissolvem"-, Ronald de Carvalho incorpora a idealização vasconceliana, isto é, a tese de que o continente americano seria o espaço criador de algo que romperá com os padrões europeus. Esse "consumo cultural" ganhou contornos mais definidos no texto "Toda América", no qual o poeta constrói a metáfora de que o continente americano é a "serenidade que absorve tudo!" e que somente por ele é que serão abertas as portas para o futuro (CARVALHO, 1926, p. 76). Nessa construção poética, Carvalho anuncia que na América cabem; "todas as imaginações, do asteca e do germano,/do guarani e do latino, do hispano e do inca, do aimoré/e do saxão, do eslavo e do africano" (CARVALHO, 1926, p. 112).

O esquema traçado pelo poeta brasileiro é bastante semelhante aos recursos utilizados por José Vasconcelos, mas com algumas diferenças. Na visão vasconceliana, vemos as quatro raças - índia, negra, branca e mongol - que darão origem à "raça cósmica", já na versão poética de Ronald de Carvalho, encontramos o descarte do "mongol”, ou seja, da raça amarela. Ainda que Ronald de Carvalho anuncia as regiões de onde virão as raças que se fundirão em solo americano: "África, Europa e Ásia vieram dançar na tua noite" (CARVALHO, 1926, p. 57), o poeta se silencia quanto ao mongol/amarelo, ou melhor, o homem asiático. A partir dessa "outra produção" proporcionada pelo poema, vemos que o poeta brasileiro ainda está impregnado pela formação racial ancorada no tripé racial: branco, negro e índio.

\section{GANPHLAC}


Ao lermos esse poema, vemos como o autor brasileiro constrói uma interpretação poética da mestiçagem muito próxima a tese da "raça cósmica". O texto "Brasil" é outro exemplo desse "consumo cultural", nele vemos as

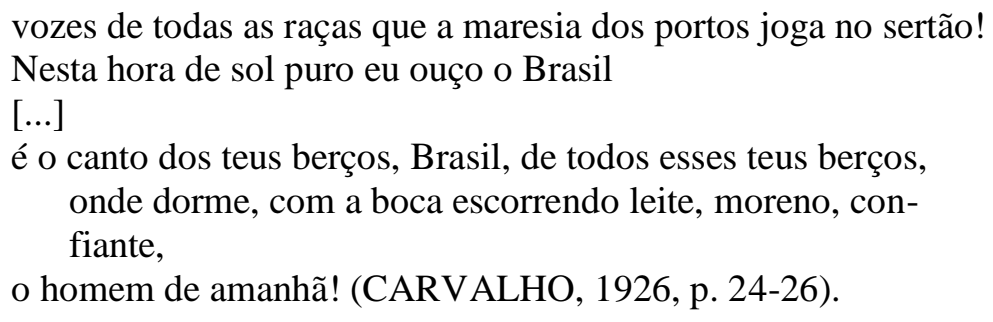

Ao ler esse texto em contraposição ao livro La raza cósmica, percebemos a concepção de História dos dois intelectuais: ambos projetam um movimento em direção ao futuro como instante propício ao surgimento do "homem de amanhã". Na montagem teleológica elaborada pelo intelectual mexicano, encontramos duas questões primordiais: em primeiro lugar, o mestiço não é o representante da degeneração da raça, como queriam os eugenistas europeus, mas uma ponte rumo à formação da raça superior; e, em segundo lugar, a América é o espaço em que surgirá o novo homem. Ao compartilhar a teleologia vasconceliana, Ronald de Carvalho insere a expectativa da fusão de todas as raças e o Brasil como espaço de nascimento desse "homem de amanhã”, ou seja, para o poeta brasileiro, não é a América que será palco do surgimento desse novo homem, mas o Brasil. Ao poetizar a tese do surgimento do novo homem e, não por coincidência, em um poema intitulado "Brasil", podemos dizer que o escritor modernista realizou uma "outra produção" do pensamento vasconceliano a partir do "consumo cultural" da tese da "raça cósmica" em seu poema Toda a América.

A partir de nossa leitura do poema Toda a América, vemos as interfaces entre as ideias vasconcelianas e a estética de Ronald de Carvalho. Admitimos que a aproximação das duas perspectivas, reforçada pelas viagens diplomáticas, fazem parte de um projeto de construção identitária das nações latino-americanas na década de 1920. Além dos fortes indícios de compartilhamentos das ideias encontradas no poema Toda a América, o livro Itinerário: Antilhas, Estados Unidos e México (1935), de Ronald de Carvalho, expõe com mais clareza sua apreciação sobre José Vasconcelos. Para o poeta brasileiro, o intelectual mexicano é um "homem honrado, o homem que injetou na arte mexicana o sangue virgem da plebe" (CARVALHO, 1935, p. 99). Nesse

\section{GANPHLAC}


sentido, a visita de José Vasconcelos ao Brasil e o convite feito à Ronald de Carvalho para visitar o México encontrou seu ponto de contato na ideia de que no solo americano germinará a semente do "homem de amanhã".

Apesar da forte expressividade do poema de Ronald de Carvalho, não podemos colocá-lo como uma obra que inaugura a incorporação da mestiçagem no fazer poética. Segundo Mônica P. Velloso (2010), muitos escritores do início do século XX assimilaram o caráter mestiço da cultura, por exemplo, Juca Mulato (1917), de Menotti del Picchia e Urupês (1918), de Monteiro Lobato. No entanto, em muitas dessas produções literárias predominava a visão pessimista da nacionalidade, ou seja, a grande maioria dos literatos liam a brasilidade por intermédio da cartilha do darwinismo social, distinguindo superiores e inferiores em função das etnias. $\mathrm{O}$ que podemos afirmar é que Ronald de Carvalho aborda a mestiçagem positivamente em diálogo com José Vasconcelos. Na próxima seção veremos que essa condição é reforçada ainda mais na composição do poema Martim Cererê. Além desses dois poemas, outros modernistas também incorporaram o conjunto de ideias de José Vasconcelos em seu fazer literário foi Plínio Salgado.

Plínio Salgado chegou à capital paulista em 1920, logo se empregando no Correio Paulistano, órgão oficial do Partido Republicano Paulista (PRP). Nesse periódico, fez amizade com Menotti del Picchia e, pouco tempo depois, com Cassiano Ricardo. A princípio, manteve posição cautelosa diante do movimento modernista, mas a partir de 1924 se assume como modernista, inclusive liderando alguns movimentos literários. Em 1927, com seus antigos parceiros do Correio Paulistano, empreende campanha literária em torno do movimento verde-amarelo, grupo geralmente associado à vertente nacionalista do modernismo. Entre 1925 e 1927, dirige junto com Menotti del Picchia e Cassiano Ricardo a revista Novíssima, em 1926 publicou O estrangeiro romance que foi bem recebido nos meios modernistas - e em 1927 publica o livro manifesto verde-amarelista intitulado O Curupira e o Carão ${ }^{9}$. Em 1928, Plínio Salgado encabeça o Movimento da Anta ${ }^{10}$, no qual exaltava o indígena, particularmente o tupi,

\footnotetext{
${ }^{9}$ Essa coletânea publicada em setembro de 1927 pela editora Hélios LTDA é considerada como o documento síntese do verde-amarelismo e os primeiros pressupostos do Movimento Anta. Annateresa Fabris (1994, p. 238) defende que na luta entre o Curupira e o Carão, divulgada na coletânea, inaugurou a luta do presente contra o passado.

${ }^{10}$ No que se refere à Revolução da Anta, Maria L. Guelfi (1987) defende que ela foi resultado das críticas verde-amarelas contra a Antropofagia e, que ao contrário da diversidade apregoada pelas ideias do verde-
}

\section{GANPHLAC}


como o portador da autêntica origem nacional. Em 1929, publicou Literatura e Política, obra em que expressava ideias nacionalistas de cunho fortemente antiliberal e agrarista, inspirada principalmente nas teses de Alberto Torres e Oliveira Viana.

A coletânea $O$ Curupira e o Carão é formada por um conjunto de artigos escritos entre 1922 e 1927 por Cassiano Ricardo, Menotti del Picchia e Plínio Salgado, em outras palavras, a tríade verde-amarela. Nesse documento verde-amarelista, essa tríade afirma que alguns desacordos não deveriam se refletir na constituição do grupo, o que importava era cada um criar "um pensamento, uma arte e uma política genuinamente brasileira" (PICCHIA, 1927, p. 56). Para esses escritores, o verdeamarelismo estava pautado na liberdade de cada um procurar o Brasil como quisesse, embora pouco tempo depois, Plínio Salgado começasse a repensar seu ideário (COELHO, 2017).

No artigo de Plínio Salgado intitulado "Raça harmoniosa", o intelectual aborda temas próximos às teses defendidas pelo intelectual mexicano. Ao descrever seu pensamento frente ao "tema racial", Salgado defende que

o Novo Mundo parece estar destinado a ser a grande pátria da raça harmoniosa, resultado de íntimas correspondências de todas as raças. E, na América, nenhum país, como o Brasil se reserva ser a pátria universal. Nela se conjugam, como num resumo estupendo, todas as realidades terrestres, humanas e geográficas [...] Na diversidade dos climas, está justamente a possibilidade do fenômeno da formidável elaboração da humanidade do futuro [...] o prodigioso fenômeno político da nossa unidade, terão como consequência num dia remoto, o aparecimento de uma raça cósmica, tipo superior da humanidade, a raça harmoniosa (CORREIO PAULISTANO, 10 de outubro de 1926, p. 3).

Ao defender o encontro de todas as raças que se daria no Brasil, Plínio Salgado nomeia essa fusão de "raça harmoniosa", a qual seria um tipo superior de humanidade resultante de todas as realidades humanas e geográficas. Como no poema "Brasil" de Ronald de Carvalho, esse artigo de Plínio Salgado aponta o Brasil como o lugar propício para o surgimento de um novo tipo de humanidade. Ambos textos em diálogo com o ensaio La raza cósmica demonstram um alto nível de intercâmbio cultural entre

amarelismo, a Escola da Anta buscava a "unidade de uma consciência brasileira com base nos estudos indígenas" (p. 173). De acordo com a autora, essa escola pretendia o retorno às origens, às tradições, e combatia o passadismo estético (p. 179).

\section{GANPHLAC}


esses projetos. O “consumo cultural” por parte de Plínio Salgado chega ao nível extremo de incorporar os pressupostos defendidos pelo intelectual mexicano em seu projeto político-literário em fins da década de 1920.

No início de 1927, o autor de O estrangeiro retoma essas posições e deixa claro sua adesão às teses vasconcelianas no artigo intitulado "Em defesa da Anta". Esse artigo traz explicitamente a apropriação dessas teses para defender suas posições políticas e literárias. Para Plínio Salgado, a intelectualidade brasileira deverá lançar "uma política americana" que defenderá a união "de todos os elementos integrantes no barro formador da grande raça futura, visionada com verdadeiro senso divinatório por José Vasconcelos" (CORREIO PAULISTANO, 17 de janeiro de 1927, p. 3). Nesse artigo, o futuro líder integralista pretende deixar público e ao mesmo tempo convencer seus parceiros verde-amarelistas do significado da "Revolução da Anta". Meses depois de publicar esse artigo, Plínio Salgado volta ao tema no texto "Formação Nacional". Nessa exposição, o escritor afirma que quer "um brasil brasileiro" e que não diz "isso por patriotismo, mas por humanidade" (CORREIO PAULISTANO, 19 de maio de 1927, p. $3)$.

Essas posições ensaiadas em artigos de jornal serão sintetizadas, ainda no ano de 1927, no livro coletânea $O$ curupira e o carão. Plínio Salgado retoma as teses vasconcelianas para anunciar a missão do Brasil no texto "A revolução da Anta", publicado na referida coletânea. Para esse verde-amarelista, a mistura das raças abrirá "um caminhar uniforme para a realização de um tipo futuro de americano, a 'quinta raça', como a denomina José Vasconcelos" (SALGADO, 1927, p. 93). Assim como Ronald de Carvalho, Plínio Salgado expõe publicamente sua simpatia com as teses do intelectual mexicano. Ambos escritores destacam os enunciados da mistura racial e o surgimento de uma "nova raça" como missão e essência do elemento nacional, em outras palavras, da brasilidade. No caso específico de Plínio Salgado, as teses vasconcelianas não estão presentes apenas em seus artigos de opinião, mas compõem seu projeto político-literário divulgado na coletânea $O$ curupira e o carão.

O documento que sintetiza as posições políticas e literárias de Plínio Salgado sob a égide verde-amarela foi o manifesto "Nheengaçu verde-amarelo" ${ }^{11}$ ". Nesse

\footnotetext{
${ }^{11}$ Apesar dos desacordos entre os verde-amarelos, o manifesto "Nheengaçu verdeamarelo" foi assinado por Plínio Salgado, Cassiano Ricardo, Menotti del Picchia, Alfredo Ellis Júnior e Cândido Motta Filho. De acordo com El Dine (2010), entre a tríade verde-amarela era evidente o desencontro de ideias, cujo
}

\section{GANPHLAC}


manifesto, podemos ver mais de perto o "consumo cultural" das teses de José Vasconcelos pelo grupo. Para justificar a afirmação de que é no Brasil que se encontrará a "raça futura", esses signatários deixam claro que se apoiam na "opinião bem fundamentada do sociólogo mexicano Vasconcelos" (apud TELES, 1978, p. 303). Para os verde-amarelos, o intelectual mexicano já havia defendido que

é de entre as bacias do Amazonas e do Prata que sairá a "quinta raça" a "raça cósmica", que realizará a concórdia universal, porque será filha das dores e das esperanças de toda a humanidade. Temos de construir essa nação, integrando na Pátria Comum todas as nossas expressões históricas, étnicas, sociais, religiosas e políticas (apud TELES, 1978, p. 303-304).

Baseando-se nas teses vasconcelianas, o manifesto deixa explícito que a tese da "raça cósmica" vem ao encontro das ideias do grupo, pois todos concordam que a colonização ocorrida no Brasil significou "a proclamação de direitos das raças e a negação de todos os preconceitos" (apud TELES, 1978, p. 301). Para os intelectuais signatários do manifesto, no Brasil "não há preconceitos de raça", "preconceitos religiosos" e "preconceito político", pois esse é "um país de migração e continuaremos a ser refúgio da humanidade por motivos geográficos e econômicos" (apud TELES, 1978, p. 304). Por essas palavras, vemos que o suposto sentimento de bondade do brasileiro e a ausência de preconceitos - já idealizado por Vasconcelos em La raza cósmica - é apropriado pelo grupo para defender que no Brasil se formará a humanidade do futuro.

A partir da leitura do poema Toda a América de Ronald de Carvalho e dos artigos de Plínio Salgado, podemos observar a exaltação da mestiçagem e a expectativa do surgimento de um novo homem. Utilizando a produção desses dois modernistas, não há como negar o "consumo cultural" das teorias vasconcelianas e, concomitantemente, uma "outra produção" do ensaio La raza cósmica.

É consenso que José Vasconcelos elegeu a América como a terra mais adequada à abertura para novas culturas e, ao se inspirarem nessa premissa, esses modernistas pretenderam consolidar a posição de que o Brasil seria o lugar ideal para o surgimento

desdobramento foi a dissolução do grupo literário em grupos políticos: o Integralismo, de Plínio Salgado, e o Movimento Bandeira, de Menotti Del Picchia e Cassiano Ricardo. Sobre os desdobramentos dos desacordos entre Plínio Salgado e outros verde-amarelos ver também: COELHO, George Leonardo Seabra. Cassiano Ricardo e Martim Cererê: um Poema em Transformação (1927-1936). Estudos Históricos Rio de Janeiro, vol. 30, no 62, p. 623-642, setembro-dezembro 2017.

\section{GANPHLAC}


do "homem do amanhã". Ao inserir a miscigenação como característica dos povos da América, e primordialmente do Brasil, esses escritores buscaram uma maneira de encaixar o Brasil no conjunto das Nações latino-americanas via José Vasconcelos. Ao agirem desta forma, os dois escritores almejavam realizar esse encaixe, pois se autodenominavam modernos, sendo assim, pretendiam pôr em ação suas práticas discursivas ao defenderem uma arte com função social e política.

Baseando-se na descrição que esses intelectuais faziam da formação racial do brasileiro, veremos no próximo tópico como as teses de José Vasconcelos influenciaram, de modo mais pontual, a escrita do poema Martim Cererê de Cassiano Ricardo. Até o momento, encontramos a equivalência temática entre os escritores brasileiros e o intelectual mexicano, tendo como foco a exaltação da mestiçagem, a promessa de surgimento do "homem síntese" e o papel que as nações latino-americanas têm de cumprir no futuro. Nessa última seção, demonstraremos que essa equivalência temática permaneceu de forma mais intensa no poema Martim Cererê. Sendo assim, esperamos que fique claro o intercâmbio entre Cassiano Ricardo e o campo intelectual latino-americano, tal qual uma "outra produção" das ideias vasconcelianas. Veremos que o autor se manteve preso à exaltação da mestiçagem como elemento fundante da criação de uma "nova raça" no Brasil. Esse esclarecimento pode, aliás, sugerir um outro caminho para entender as apropriações das teses da "raça cósmica" na fundamentação dos pressupostos verde-amarelos.

“Consumo cultural” e "outra produção" de La raza Cósmica no poema Martim Cererê Dois anos após a publicação do livro La raza cósmica, foi publicado no Brasil o Martim Cererê (1927) de Cassiano Ricardo. Para compreender a inserção do escritor no debate literário modernista em São Paulo é importante destacar que ele estava residindo desde 1919 em Vacaria no Rio Grande do Sul. Somente em 1923, o poeta retorna à São Paulo e ingressa no jornal Correio paulistano, onde conhece e constrói amizade com Plínio Salgado e Menotti del Picchia. Apesar de ter iniciado sua carreira literária em 1915, com o livro parnasiano Dentro da noite, somente a partir de 1923 dá os primeiros passos para a revisão em seu comportamento literário. Amilton M. Monteiro (2003) avalia que com a direção da revista Novíssima entre 1923 e 1927, Cassiano Ricardo aproxima-se das tendências artísticas derivadas da Semana de 22. O ano de 1925 é

\section{GANPHLAC}


considerado como sua estreia modernista com a publicação do livro de poemas Borrões de verde e amarelo. Após publicar Vamos caçar papagaios (1926), o poeta publica oficialmente o Martim Cererê, considerado por seus críticos como sua obra-prima modernista, a qual sofreu forte influência da tese da "raça cósmica".

Menos de uma semana depois da divulgação do artigo "Em defesa da Anta", de Plínio Salgado, Cassiano Ricardo divulga o artigo "Nheengaçu verdeamarelista", no qual o poeta paulista deixa público a admissão do símbolo proposto por Plínio Salgado, aproveitando a oportunidade para deixar explícita sua simpatia com as teses do intelectual mexicano. Nesse texto, o escritor defende que é de "nossa paisagem étnica" que sairá “o 'homem síntese', referido por Vasconcelos na raça cósmica” (CORREIO PAULISTANO, 21 de janeiro de 1927, p. 2). O argumento de que o Brasil tem uma missão a cumprir também é encontrado no artigo "A Poesia dos cafezais", no qual o poeta defende que no Brasil ocorre a verdadeira democracia, pois aqui "todos os povos de todas as procedências [...] vem fundir" em uma só raça. De acordo com o poeta, a posição verde-amarelista - agora sob o signo da "Revolução da Anta" - apoia-se nas "palavras de certo pensador mexicano que anteviu a formação da raça cósmica" (CORREIO PAULISTANO, 3 de julho de 1928, p. 3). Vejamos como a simpatia do poeta pela tese da "raça cósmica" - fusão das raças, formação do "homem síntese" e destino a cumprir -materializaram-se no poema Martim Cererê.

O poema em questão exalta os heróis paulistas, a modernização da cidade de São Paulo e a miscigenação racial como inspiração poética. Luiza F. Moreira (2001) entende o Martim Cererê como uma mescla de folclore, miscigenação racial e episódios históricos unidos para explicar a formação da Nação. A partir dessa mistura, Mônica P. Velloso (2010) considera que o poeta construiu uma mitificação capaz de abranger todos os brasileiros em todos os tempos. As autoras concordam com a posição de que Cassiano Ricardo utilizou elementos folclóricos e históricos, os quais criaram uma narrativa do surgimento de uma nova raça na América. Com a leitura proposta aqui, veremos que muitos estudos dedicados a esse poema ignoraram uma especificidade: o “consumo cultural” das teses defendidas por José Vasconcelos.

Além da ideia de que o Martim Cererê é um poema único, formado por materiais díspares, cuja intenção era abranger o país inteiro a partir da narrativa mítica da origem da Nação, uma das peculiaridades da obra são as alterações que o poeta

\section{GANPHLAC}

Revista Eletrônica da ANPHLAC, ISSN 1679-1061, №. 25, p. 183-221, Jul./Dez., 2018.

http://revista.anphlac.org.br 
empreendeu no texto. Poderíamos, à primeira vista, supô-las decorrentes das revisões comuns à publicação de novas edições. Contudo, nas revisões ao longo das edições, Cassiano Ricardo alterou não somente a escrita e a estética, mas também o número de poemas $^{12}$. Outra peculiaridade do Martim Cererê está no fato de ter sido publicada nove anos após seu lançamento sua sexta edição, fato raro no mercado literário, especialmente em se tratando de um poema. Como contraponto desse "sucesso" editorial, podemos destacar que somente em 1937 as segundas edições de Macunaíma e Cobra Norato seriam publicadas ${ }^{13}$. Frente às peculiaridades desse poema e posições de Cassiano Ricardo sobre o pensamento de José Vasconcelos, veremos como o poeta incorporou as teses vasconcelianas em sua obra.

A leitura da epígrafe inicial do Martim Cererê é um bom exemplo sobre as intenções raciais do texto, representações raciais que beberam nos escritos de José Vasconcelos. Escrita por Plínio Salgado, a epígrafe anuncia:

Se ele foi o curumi das tabas, o moleque da senzala, deve ser também o italianinho das nossas fazendas de café e o escoteiro das nossas escolas. É a criança travessa. E, como criança, é a própria imagem da Pátria (RICARDO, 1927b).

Tendo a obra de José Vasconcelos como pano de fundo, a leitura da epígrafe de Plínio Salgado exemplifica a "outra produção" que o poema de Cassiano Ricardo enseja. Vemos na epígrafe as três raças: o indígena, na imagem do "curumi", o negro, representado pelo "moleque da senzala" e o branco, na figura do "italianinho". Para

\footnotetext{
${ }^{12}$ Assim, vemos que na edição de 1927 eram 57 poemas em 167 páginas; na de 1928, 42 poemas em 127 páginas; na de 1929, 47 poemas em 126 páginas; na de 1932, 51 poemas em 139 páginas; na de 1934, 55 poemas em 180 páginas; e na edição de 1936, 60 poemas em 227 páginas (COELHO, 2017).

${ }^{13}$ Em outro artigo tive a oportunidade de destacar outras variáveis comparativas entre o Martim Cererêe e essas duas obras. Na ocasião demonstrei que as seis edições do Martim Cererê somam mais de cinco mil exemplares contra pouco mais de dois mil de Macunaíma e Cobra Norato juntos. Ainda no que concerne à comparação, salientei que a primeira edição de Macunaíma veio a público em 1928 com tiragem de 800 exemplares, pelas Oficinas Gráficas de Eugênio Cupolo; já a segunda edição foi feita pela Livraria José Olympio Editora em 1937, com tiragem de mil exemplares. O poema Cobra Norato foi publicado pela primeira vez em 1931 pela Editora Irmãos Ferrais e sua segunda edição foi em 1937, em impressão artesanal de Mestre Armindo Di Monaco. Ambas as edições de Cobra Norato tiveram apenas 150 exemplares. Além da quantidade de exemplares, apenas a segunda edição do romance de Mário de Andrade foi publicada por uma editora de sucesso, enquanto o Martim Cererê teve três edições publicadas pela Editora Hélios - importante empresa editorial de publicação de obras de vários modernistas - e uma pela consagrada Livraria José Olympio Editora (COELHO, 2017).
}

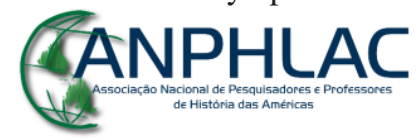

Revista Eletrônica da ANPHLAC, ISSN 1679-1061, №. 25, p. 183-221, Jul./Dez., 2018.

http://revista.anphlac.org.br 
poetizar temporalmente o surgimento de uma da nova raça no continente americano, Cassiano Ricardo narra essa fusão no poema "Raça nova", um dos poucos textos presente em todas as seis primeiras versões analisadas. Tal como a maior parte dos textos pertencentes à obra, esse poema também sofreu alterações, mas que não interferiram no sentido encontrado na primeira versão publicada em 1927: anunciar o surgimento da nova raça. Nesse texto, Cassiano Ricardo narra tal surgimento a partir do encontro dos povos "vermelhos", "pretos" e "brancos", encontro racial este ilustrado por Di Cavalcante em uma imagem inserida na versão de 1928, vejamos;

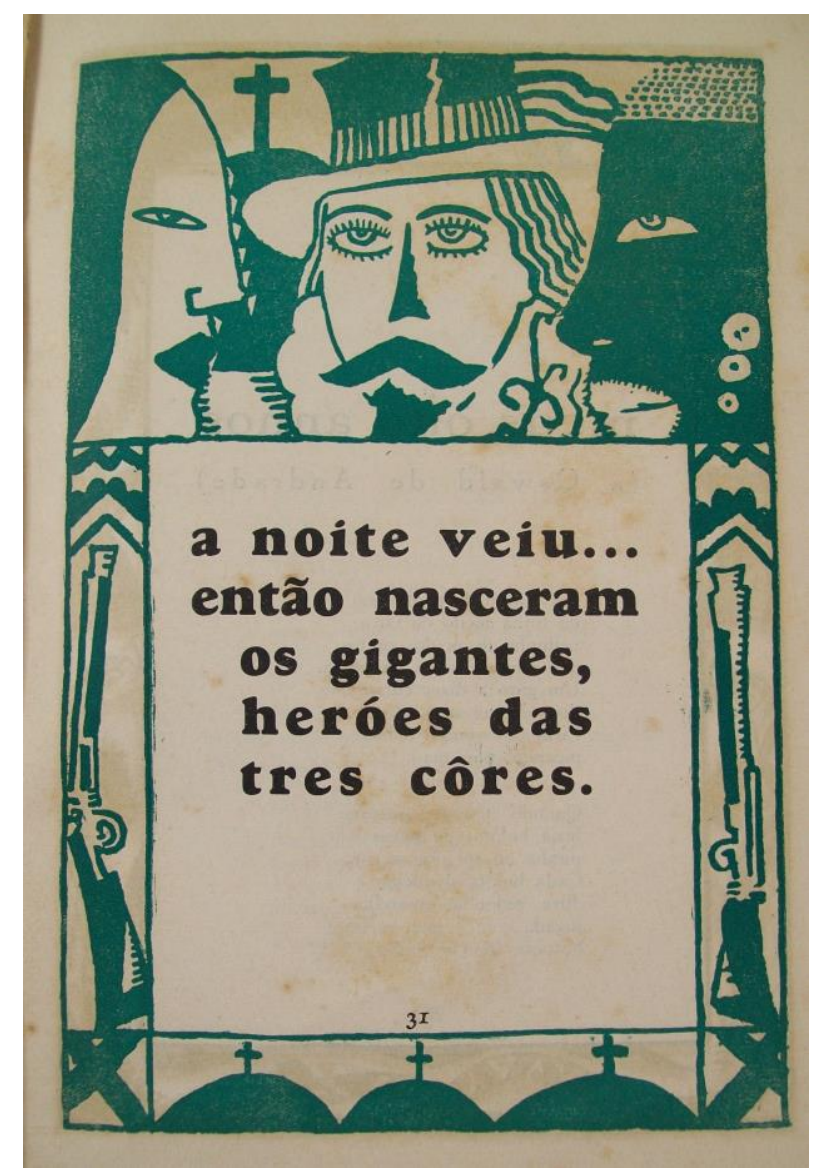

Figura 1 - Ilustração da quarta seção Martim Cererê (1928).

Nessa ilustração, que abre a quarta seção do poema, vemos o encontro das três raças. A respeito de tal idealização racial, José Vasconcelos também a utiliza em seu ensaio. Para o intelectual mexicano,

el hombre nórdico, que hoy es maestro de acción, pero que tuvo comienzos humildes y parecía inferior, en una época en que ya habían

\section{GANPHLAC}

Revista Eletrônica da ANPHLAC, ISSN 1679-1061, №. 25, p. 183-221, Jul./Dez., 2018.

http://revista.anphlac.org.br 
aparecido y decaído varias grandes culturas: el negro, como una reserva de potencialidades que arrancan de los días remotos de la Lemuria; el indio, que vio perecer la Atlántida (VASCONCELOS, 1948, p. 53).

Levando em consideração o entendimento de Vasconcelos sobre a fusão das três raças - branco/ação, negro/potencialidade e índio/mistério - que formariam a "raça cósmica" e sua apropriação na elaboração da epígrafe do Martim Cererêe, vemos que ocorre a materialização dos comentários que Plínio Salgado e Cassiano Ricardo haviam expressado sobre o intelectual mexicano a partir da imprensa. Como apresentado, tais escritores defendiam que criação da "raça cósmica" seria um caminho a ser seguindo pela intelectualidade brasileira. sendo assim, a partir do reconhecimento do pensamento do intelectual mexicano por parte desses dois escritores, podemos afirmar que o Martim Cererê experimentou os enunciados que compõem o pensamento de José Vasconcelos. Além do poema ser um espaço de experimentação, a apropriação desses enunciados também serviu - para Cassiano Ricardo - como chave explicativa para a problemática racial brasileira.

A leitura dessa epígrafe também nos ofereceu a oportunidade de discutir outra temporalidade do poema: a produção cafeeira. No que se refere ao branco no poema, esse tronco racial cumpre um papel primordial, pois é ele quem chega ao Novo Mundo, traz a civilização, possibilita a união entre o índio e o negro, comanda a conquista do território na figura do bandeirante, representa o imigrante e quem guiará a Nação na modernidade. Verificamos que o poeta não foge à valorização do branco, o que poderia expressar sua adesão à eugenia racial europeia. Essa afirmação estaria equivocada caso o pesquisador não ressaltasse que a valorização da raça branca é amenizada pela tese da miscigenação composta por José Vasconcelos. Apesar dessa ressalva, em José Vasconcelos o branco também tem um papel fundamental na criação de uma nova raça. Em uma passagem de seu livro La raza cósmica, o ensaísta demonstra a importância dada ao branco no processo de miscigenação. Para o intelectual mexicano,

después de organizarse en Europa, se ha convertido en invasor del mundo [...] su misión es servir de puente. El blanco ha puesto al mundo en situación de que todos los tipos y todas las culturas puedan fundirse. La civilización conquistada por los blancos, organizada por nuestra época, ha puesto las bases materiales y morales para la unión

\section{GANPHLAC}


de todos los hombres en una quinta raza universal, fruto de las anteriores y superación de todo lo pasado.

La cultura del blanco es emigradora; pero no fué Europa em conjunto la encargada de iniciar la reincorporación del mundo rojo a las modalidades de la cultura preuniversal, representada, desde hace siglos, por el blanco (VASCONCELOS, 1948, p. 16).

Como vemos, José Vasconcelos aponta que o branco serviu de ponte entre todos os tipos humanos e culturais, assim como ofereceu as bases materiais e morais para a união de todos os homens na criação da raça universal. Embora exalte as características colonizadoras do branco, tanto o intelectual mexicano quanto Cassiano Ricardo defendem que sua potência somente ganharia dimensão apologéticas no continente americano, pois é nesse território que as diferenças raciais e culturais se diluiriam.

Retornando à análise da narrativa do Martim Cererê, o leitor pode perceber que as três raças - o branco-comando, o índio-movimento e o negro-trabalho ${ }^{14}$ - unidas no período colonial esperam a chegada do imigrante para formar a "cruz do cruzamento". Em Cassiano Ricardo, a chegada do imigrante - o elemento que simboliza a quarta raça - ao Brasil completa esse elemento metafórico que possibilitará o nascimento da "raça cósmica". O poeta brasileiro anuncia que é nesse espaço que se encontram todos os: "Homens feitos de bronze/marcados por todos os sois,/por todas as chuvas, por todos os ventos,/por todos os climas, por todos/os sofrimentos (RICARDO, 1932, p. 106). No texto "Minha terra tem palmeiras", publicado em 1927 no Correio Paulistano, o poeta utiliza a metáfora das núpcias para inserir os imigrantes na formação de uma nova raça, em outras palavras, a formação da "quinta raça", do "homem síntese" ou da "raça cósmica" (CORREIO PAULISTANO, 11 de janeiro de 1927, p. 4).

Como é possível observar, o poeta utiliza enunciados ligados às posições vasconcelianas para fundamentar seu entendimento sobre a questão racial no Brasil. Como reforço a tal afirmação, o imigrante somente é incorporado no instante em que o autor narra o recorte temporal em que o Estado brasileiro abre os portos para a imigração. No poema "Soldados Verdes" - outro texto encontrado em todas as versões

\footnotetext{
${ }^{14}$ Essas formulações conceituais - branco-comando, índio-movimento e negro-trabalho - foram fundamentadas na Tese de Doutorado orientada pela Prof. ${ }^{a}$ Dr. ${ }^{a}$ Fabiana Fredrigo e defendida pelo autor desse artigo em 2015. Essa tríplice formulação conceitual deriva-se da análise do poema Martim Cererê em consonância com o projeto modernizador e político defendido por Cassiano Ricardo, onde a Democracia Social Brasileiro fundamentava-se a partir da hierarquização racial brasileira e suas funções econômicas. Ver: COELHO, George Leonardo Seabra. O bandeirante que caminha no tempo: apropriações do poema "Martim Cererê" e o pensamento político de Cassiano Ricardo. Disponível em: <https://pos.historia.ufg.br/up/113/o/T2015-12.pdf> Acessado em: 12/05/2018.
}

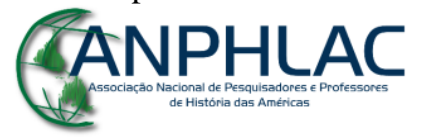

Revista Eletrônica da ANPHLAC, ISSN 1679-1061, №. 25, p. 183-221, Jul./Dez., 2018.

http://revista.anphlac.org.br 
e um dos raros que não sofreram alterações -, o poeta anuncia que "um grande exército colorido de imigrantes" chega para colonizar a terra (RICARDO, 1932, p. 86). A imigração e seu papel para a formação da "raça futura" estão espalhados por toda a narrativa do Martim Cererê. Por um lado, essa construção é inovadora pelo fato de o imigrante tornar-se ator na formação racial do Brasil e, por outro, a inserção do imigrante nessa formação racial deu-se em oposição ao Peri, ao Jeca Tatu e à tríplice formação étnica. A partir da inserção do imigrante como personagem em um poema que pretende narrar uma construção específica de brasilidade, novamente vemos indícios da forte influência da tese da "raça cósmica".

Em um diário carioca, podemos ler um texto de José Vasconcelos no qual o intelectual mexicano defende que a "imigração estrangeira produziu no Brasil uma nova raça de extraordinária beleza [...] pela mistura de brasileiros, portugueses, italianos, alemães e polacos" (O JORNAL, 16 de setembro de 1923, p. 16). Essa concepção relacionada à imigração também ganha destaque em La raza cósmica, principalmente no capítulo dedicado à cidade de Santos. O pensador mexicano retoma a defesa de que é em São Paulo que surgirá a síntese racial, pois ali "acuden en la actualidad emigraciones latinas, que se mezclan para formar un medio en el que, si gran menoscabo de la bondad, triunfan el talento y la belleza" (VASCONCELOS, 1948, p. 75). Para o pensador mexicano, o processo de miscigenação ocorreria apenas na América Latina, sendo o Brasil um país de grandes possibilidades, pois esse local aberto à mestiçagem e cosmopolita por natureza - tem a missão de servir de berço para o nascimento de uma nova humanidade.

Mesmo que seja notória a influência do pensamento do intelectual mexicano na composição desse poema, não podemos menosprezar que tal brasilidade miscigenada também tem suas raízes no cosmopolitismo paulista. No ponto de vista de Cassiano Ricardo, a cidade de São Paulo possibilita que cem raças se debatam no seu xadrez etnológico e, em razão das levas migratórias, a força étnica do português, do silvícola e do negro foram vencidas pelos imigrantes. Essa visão marcou profundamente a perspectiva racial descrita no Martim Cererê, pois o imigrante se integra ao poema como colaborador dessa nova Nação. Explicitamente, o imigrante viera para contribuir com o trabalho nas lavouras de café e depois na cidade industrial. Implicitamente, o imigrante veio contribuir com a formação da família, pois a musa de desejo do eu

\section{GANPHLAC}


poético é uma mulher branca - russa, húngara, alemã, turca ou italiana -, mas nunca uma índia ou negra.

Poderíamos considerar que a quarta raça posta no Martim Cererê seria qualquer leva imigratória, no entanto, ocorre um processo de seleção, pois, tal qual em Ronald de Carvalho, não aparece nenhuma menção ao asiático no poema de Cassiano Ricardo. A diferença entre o escritor mexicano e os dois poetas brasileiros na descrição das quatro raças formadoras da "raça cósmica" está na ausência do mongol. O poeta de Martim Cererê traz para sua narrativa o branco (o português e depois o italiano), o índio (sem diferenciar os grupos étnicos), o negro (sempre posto como escravo) e o imigrante (formado por todos os grupos imigratórios, mesmo o asiático). Sem menção alguma ao asiático, Cassiano Ricardo apenas poetiza o imigrante vindo de qualquer parte do planeta para se unir ao exército das três cores na formação da raça nova.

Para representar a reunião de todas as raças e a expectativa de uma outra humanidade, o ilustrador - na capa da edição de 1928 do Martim Cererê - insere no canto superior direito uma metáfora criada por Cassiano Ricardo. A constelação do Cruzeiro do Sul é apropriada e transformada em alegoria para representar o encontro racial ocorrido no Brasil.

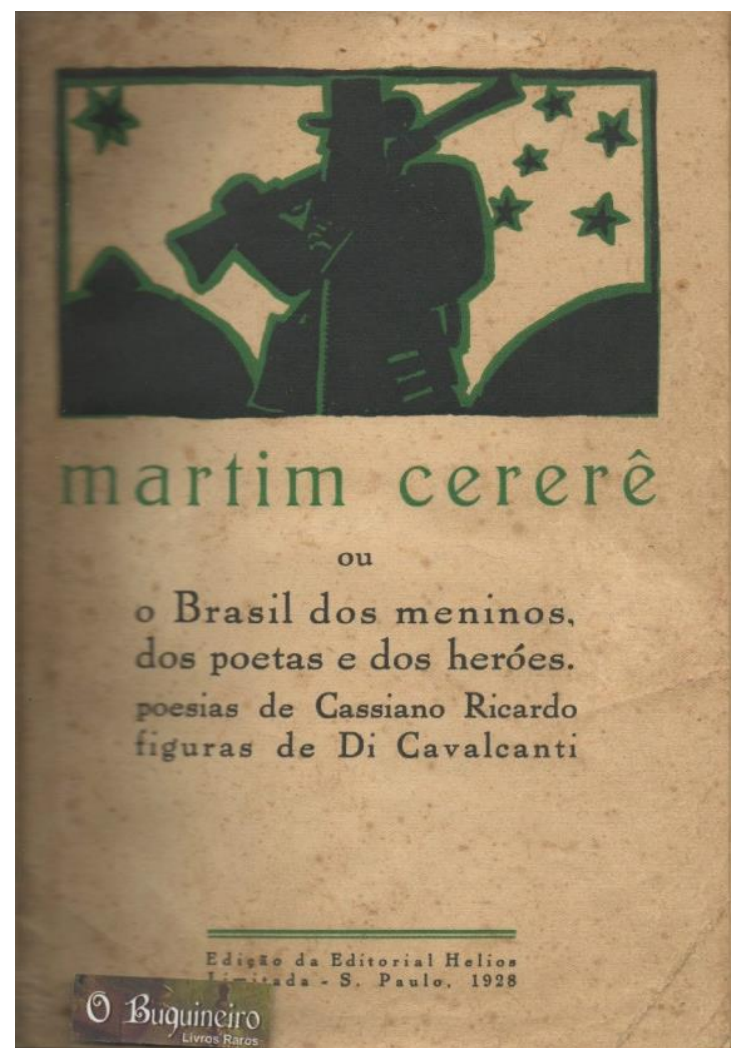

Figura 2 - Ilustração da capa do Martim Cererê (1928)

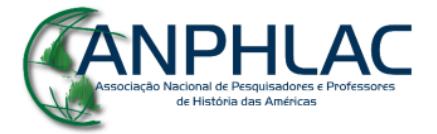

Revista Eletrônica da ANPHLAC, ISSN 1679-1061, №. 25, p. 183-221, Jul./Dez., 2018.

http://revista.anphlac.org.br 
A constelação do Cruzeiro do Sul é apropriada por Cassiano Ricardo para representar o encontro das quatro raças que darão origem à quinta raça. Novamente enfatizamos que a eugenia baseada na formação racial miscigenada não é uma criação do poeta brasileiro, mas, como vemos ao longo deste texto, tal formulação eugênica fundamentada na união de quatro raças para formar uma "quinta raça" fora idealizada por José Vasconcelos. No ensaio La raza cósmica, o intelectual mexicano afirma que "tenemos entonces las cuatro etapas y los cuatro troncos: el negro, el indio, el mogol y el blanco" (VASCONCELOS, 1948, p. 16). Em outra passagem do livro, José Vasconcelos amplia esse enunciado ao defender que se deve:

levantarse cuatro grandes estatuas de piedra de las cuatro grandes razas contemporáneas: la Blanca, la Roja, la Negra y la Amarilla, para indicar que la América es hogar de todas, y de todas necesita [...] a la creación de una raza hecha con el tesoro de todas las anteriores, la raza final, la raza cósmica (VASCONCELOS, 1948, p. 54).

No poema "Marcha final" da versão de 1928 - uma versão modificada do poema "Marcha heroica" da edição de 1927 - Cassiano Ricardo reforça a metáfora do "Cruzeiro do Sul” como alegoria do surgimento de uma raça nova. Nesse texto, Cassiano Ricardo narra - na posição de espectador - a formação racial do brasileiro:

Diante da tua cruz, feita de estrelas vejo passar sob os meus olhos as quatro raças que depois da tragédia de todos os ódios e de todas as lutas humanas irão fundir-se pelo amor de uma só raça.

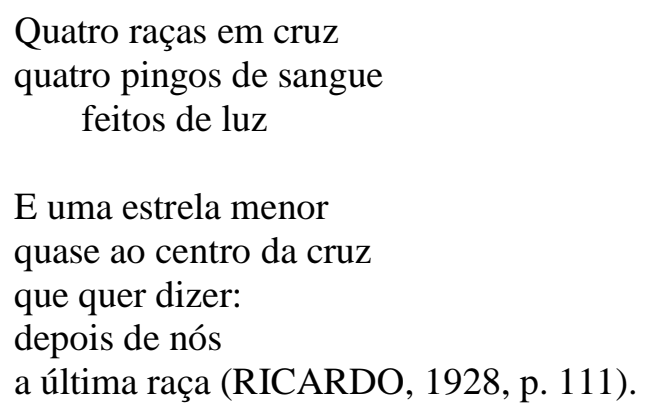

\section{GANPHLAC}


Narrando o surgimento da "última raça", Cassino Ricardo idealiza a "cruz do cruzamento" que representa "o mistério da raça futura" fruto de todas as "raças/de todas as cores" (RICARDO, 1928, p. 113). Na versão de 1934, Cassiano Ricardo nos oferece outro texto que fortalece a metáfora desse cruzamento racial no poema "Sinal do céu". Esse texto estava presente nas edições de 1927 e 1928, mas com uma narrativa totalmente diferente. Nessa nova versão, Cassiano Ricardo dá destaque ao território brasileiro como espaço que confortaria toda as raças, vejamos:

... quatro raças virão, algum dia, de quatro caminhos distantes marcados por estas estrelas que ficam nas pontas da cruz pra construir uma só raça marcada por outra estrela que é a que fica no centro da cruz.

Quatro raças virão... quando todos os ódios se acalmarem numa só aspiração;

quando todas as raças se encontrarem no mesmo roteiro; quando cessar a dispersão dos homens... e todos os destinos se cruzarem sob o céu do Cruzeiro...

Eu sou o caminho ainda obscuro por onde, afinal desfilará a humanidade do futuro.

Eu sou a cruz do cruzamento! o cruzeiro do amor universal. [...] como que pra dizer: vinde todos! Que este céu é bastante profundo e servirá de teto a todos quanto sofrem no mundo! que este céu é bastante fecundo e dará de comer a todos quantos têm fome, no mundo! que estes rios darão de sobejo para mitigar a sede a todos quantos têm sede, no mundo! (RICARDO, 1934, p. 59-60).

No decorrer das alterações realizadas nessa obra, vemos que a alegoria do "Cruzeiro do Sul" se consolida: o encontro das quatro raças, sendo a estrela central a "última raça", a miscigenação que colocará fim a todos os ódios em prol do amor

\section{CANPHLAC}


universal, e, por fim, o território brasileiro que acolherá todos aqueles que buscam a felicidade. Após narrar o encontro das quatro raças, Cassiano Ricardo, assim como Ronald de Carvalho, incorpora a teleologia vasconceliana na menção de toda a expectativa de redenção em direção ao futuro. Apropriando-se de tal recurso, o poeta anuncia que no futuro "não haverá mais ódio sobre a terra!/ e uma raça não será inimiga/de outra raça” (RICARDO, 1936, p. 81).

Essa projeção para um futuro de bondade e sem preconceito racial é marcante na obra de José Vasconcelos. Para o intelectual mexicano

no será la futura ni una quinta ni una sexta raza, destinada a prevalecer sobre sus antecesoras; lo que de alli va a salir es la raza definitiva, la raza síntesis o raza integral, hecha con el genio y con la sangre de todos los pueblos y, por lo mismo, más capaz de verdadera fraternidad y de visión realmente universal (VASCONCELOS, 1948, p. 31).

Para José Vasconcelos, no "suelo de América hallará término la dispersión, allí se consumará la unidad por el triunfo del amor fecundo, y la superación de todas las estirpes" (VASCONCELOS, 1948, p. 28). Essa terra de amor e paz projetada no tempo também é apropriada por Cassiano Ricardo, como podemos ver na versão de 1936 do Martim Cererê:

E nos dias de sol, na gloria da colheita, os homens que virão dos pontos mais distantes se reunirão aqui, nativos e imigrantes, para a festa nupcial de uma outra humanidade que será feita de alegria e bondade (RICARDO, 1936, p. 83).

Ao longo do Martim Cererê, o autor coloca o território brasileiro como o espaço privilegiado para a diluição de todas as diferenças. Aqui está outra apropriação das ideias de José Vasconcelos. Em artigo - "O Brasil apreciado por um estrangeiro" escrito por José Vasconcelos e publicado em 1923, o intelectual mexicano enfatiza que o Brasil é o "país mais maravilhoso do mundo" porque

não se concebe ali a falsa arrogância, porque os habitantes e a natureza superam as mais exaltadas ficções da imaginação [...] $\mathrm{O}$ patriotismo brasileiro [...] nunca é agressivo; é patriotismo acolhedor e benévolo, que logo conquista o recém-chegado [...] Talvez nenhum

\section{GANPHLAC}


povo tenha como o Brasil o direito ao título de pátria universal $(\mathrm{O}$ JORNAL, 16 de setembro de 1923, p. 16).

Anos depois, o intelectual mexicano retoma esses argumentos em sua obra $\mathrm{La}$ raza cósmica e empresta as potencialidades que havia idealizado no Brasil para todo o continente americano. $\mathrm{O}$ intelectual mexicano afirma que:

El objeto del continente nuevo y antiguo es mucho más importante. Su predestinación obedece al designio de constituir la cuna de una raza quinta en la que se fundirán todos los pueblos, para reemplazar a las cuatro que aisladamente han venido forjando la Historia (VASCONELOS, 1948, p. 28).

Mais a frente, José Vasconcelos arremata a tese de que em todo o continente americano - com exceção da colonização saxão - nascerá uma nova raça. Para o intelectual mexicano:

Tenemos, pues, en el continente todos los elementos de la nueva Humanidad [...] Solamente la parte ibérica del continente dispone de los factores espirituales, la raza y el territorio que son necesarios para la gran empresa de iniciar la era universal de la Humanidad (VASCONCELOS, 1948, p.52-53).

Sendo assim, somente na América Latina se consumaria a humanidade futura, uma nova humanidade e uma humanidade universalista. Ao propor uma explicação redentora do mestiço latino-americano, essa nova raça aparece dotada de qualidades superiores, pois incorporaria apenas elementos positivos das quatro raças formadoras. Apesar da aparente inferioridade, desunião e fracasso dos povos da América Latina adjetivos ligados ao olhar eugênico europeu -, José Vasconcelos acredita que essa nova composição racial fará com que os latinos atinjam uma formação racial superior à dos europeus.

A partir da tese idealizada pelo intelectual mexicano, vemos como ocorre uma "outra produção" da obra La raza cósmica no poema Martim Cererê. A partir da apropriação das teses vasconcelianas, Cassiano Ricardo constrói sua visão eugênica da sociedade brasileira ao defender que o Brasil é o lugar propício para o surgimento da nova raça que preparará a humanidade do futuro. O "tema racial" e a miscigenação são uma das maiores preocupações do poeta no Martim Cererê e não a construção das bases

\section{GANPHLAC}


para o projeto político instaurado no Brasil após o golpe de 15 de novembro de 1937 ou para a elaboração do ensaio Marcha para Oeste (1940), como querem diversos estudos da trajetória do autor como, por exemplo, os trabalhos de Mônica Velloso (1983), Kátia Abud (1985), Luiza F. Moreira (2001), Vera Lúcia de Oliveira (2002), entre outros. Na construção da identidade nacional idealizada nesse poema, o autor procurou relacionar o espaço e a raça como elementos intrínsecos à origem de um novo povo na América. No que concerne a essa questão, Maurício Tenório (1994) e Laura Suárez y López Guazo (2005) afirmam que a ideologia da mestiçagem foi um traço comum na construção da identidade nacional nos países latino-americanos, tendo José Vasconcelos como um dos escritores mais influentes da década de 1920, e que, como visto nesta seção, exerceu grande influência na composição do poema Martim Cererê.

Ao elencarmos o encontro racial como um dos temas centrais do poema, podemos observar uma narrativa edificada pela hierarquização social e racial. Devemos ter em mente que para a comunidade intelectual da década de 1920, discutir raça é discutir a hierarquia, e pensar a hierarquia é pensar toda a organização social brasileira. Com base nos debates raciais desenvolvidos por José Vasconcelos, Cassiano Ricardo pode pensar as funções sociais das raças no contexto brasileiro: o indígena/natureza (raça vermelha), africano/trabalho (raça negra), branco/civilização (raça branca), imigrante/produção (raça miscigenada) e nova-raça/futuro (paz e prosperidade). Tais estruturas discursivas revelam que o discurso poético do Martim Cererê reproduziu não somente os referenciais da intelectualidade nacional, mas, como visto, representaram também o diálogo com a intelectualidade hispano-americana da década de 1920.

\section{Considerações finais}

Levando em consideração as formas como as teorias raciais europeias foram inseridas no Brasil, Lilia Schwarchz (1993, p. 243) pensa na "originalidade da cópia" desenvolvida nos espaços acadêmicos brasileiros. No presente artigo, podemos muito bem tomar de empréstimo essa afirmação para pensar como Ronald de Carvalho, Plínio Salgado e Cassiano Ricardo apropriaram-se das teorias raciais latino-americanas para compor um projeto literário: de um lado, mescla história e misticismo aborígene, e de outro, exalta a mestiçagem como característica da brasilidade. Outra contribuição deste estudo em consonância aos trabalhos de Schwarchz foi expor um outro espaço de

\section{GANPHLAC}


apropriação das teorias racistas na década de 1920, isto é, o modernismo brasileiro. Desta forma, consideramos que entre as representações mestiças de finais do século XIX e a reelaboração culturalista dos anos de 1930, podemos acrescentar o diálogo entre as teses do intelectual mexicano e a literatura moderna brasileira como fruto do pensamento eugênico latino-americano, o qual produziu uma outra versão da questão racial.

Também foi possível observar que a passagem de José Vasconcelos pelo Brasil durante as comemorações do I Centenário da Independência foi além de simples intercâmbios diplomáticos ou uma propaganda estatal mexicana, mas influenciaram parte da intelectualidade modernista brasileira. As duas conferências realizadas por José Vasconcelos nos salões da ABL são exemplos, pois representam o reconhecimento das qualidades desse intelectual no Brasil, uma vez que a Casa de Machado de Assis era na década de 1920 um dos principais cenáculos literários e intelectuais do país.

No que diz respeito ao "consumo cultural" das teses vasconcelianas na literatura modernista da década de 1920, podemos considerar que a "outra produção" de La raza cósmica nos poemas Toda a América e Martim Cererê possibilitou dar uma resposta ao problema posto à sociedade brasileira da época. Tal problema havia sido apresentado já no final do século XIX e início do século XX, o qual girava em torno da identidade nacional. Tais posições tomavam a pureza da raça como essência do sucesso ou não da Nação, no que a intelectualidade buscou uma explicação e, consequentemente, uma saída para o atraso que permeava essa sociedade mestiça e herdeira do colonialismo. Sendo assim, o "consumo cultural" das ideias vasconcelianas pela intelectualidade brasileira possibilitou a apropriação das teses da "raça cósmica" como saída para as questões identitárias e raciais nacionais. Como visto, pretendemos chamar a atenção do leitor para as intercessões entre o ensaísmo hispano-americano e o tema racial e eugênico pertencentes ao modernismo a partir do reconhecimento dos brasileiros acerca da importância de Vasconcelos.

Em relação às trocas culturais entre as teses de Vasconcelos e a intelectualidade brasileira, observamos dois exemplos: em primeiro lugar, a viagem de Ronald de Carvalho ao México, a qual resultou não apenas na aproximação diplomática entre os dois países, mas na escrita do poema Toda a América; em segundo lugar, como a teoria da "raça cósmica" exerceu grande influência nos princípios filosóficos dos escritores

\section{GANPHLAC}


paulistas vinculados ao verde-amarelismo, os quais se materializaram no manifesto "Nheengassú verde-amarelo" e no poema Martim Cererê, de Cassiano Ricardo. No que se refere ao "consumo cultural" das teses vasconcelianas no poema Martim Cererê, foi possível perceber como a posição do poeta buscou suprimir a tríade racial tradicional com a incorporação da migração estrangeira - como quarta raça - para a formação do brasileiro e, consecutivamente, da "raça futura".

De todo modo, a figura do mestiço aparece reinventada na retórica do campo intelectual latino-americano. Essa reinvenção redentora acaba por redimir a própria América Latina, palco de sua missão na concepção vasconceliana, ao mesmo tempo, redime o Brasil - como outro palco - na interpretação dos três escritores modernistas brasileiros. Ao proclamar uma identidade mestiça para o México, para toda a América Latina e consecutivamente para o Brasil, esses escritores conferem ao mestiço o cargo de harmonizador universal de todas as raças e, mais que isso, vemos diferentes formas de nomear essa "nova raça". Essa idealização é relida por Cassiano Ricardo para definir o brasileiro como o "homem síntese", ou o "homem de amanhã" de Ronald de Carvalho, a "raça harmoniosa" de Plínio Salgado, ou até a "raça cósmica" de José Vasconcelos.

\section{Bibliografia}

ASCENSO, João Gabriel da Silva. A redenção cósmica do mestiço: inversão semântica do conceito de raça na Raza Cósmica de José Vasconcelos. Estudos Históricos, Rio de Janeiro, vol. 26, n. 52, 2013, p. 294-315

BARROS, João. Alma da América. In. A Noite, ano XVI, n. 5.221, p. 1, 4 de junho de 1926.

BOTELHO, André. Circulação de ideias e construção nacional: Ronald de Carvalho no Itamaraty. Estudos Históricos, Rio de Janeiro, no 35, janeiro/junho de 2005, p. 69-97.

BRITO, Sylvio de. José Vasconcelos e a instrução pública mexicana. In. O Jornal, ano V, n. 1231, p. 4, 11 de abril de 1923.

CARVALHO, Leonardo Dallacqua de. A identidade da "raça cósmica": a experiência da eugenia no México. História, Ciências, Saúde. Manguinhos, Rio de Janeiro, v.23, supl., dez. 2016, p.268-270

CARVALHO, Ricardo Souza de. Ronald de Carvalho: um moderno acadêmico. Graphos. João Pessoa, v. 8, n. 1, Janeiro/Julho de 2006, p. 75-80.

CARVALHO, Ronald. Itinerário: Antilhas, Estados Unidos e México. São Paulo: Companhia editora Nacional, 1935. 111 p.

CARVALHO, Ronald. Toda a América. Rio de Janeiro: Pimenta de Mello e CIA, 1926. $151 \mathrm{p}$.

CHARTIER, Roger. À Beira da Falésia. A História entre Certezas e Inquietudes. Trad. Patrícia Chittoni Ramos. Porto Alegre: Ed. Universidade/UFRGS, 2002. 277 p.

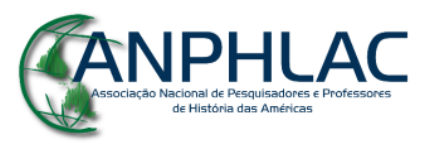


CHARTIER, Roger. História cultural: entre práticas e representações. Rio de Janeiro: Difel-Bertrand, 1990. 239 p.

COELHO, George Leonardo Seabra. O bandeirante que caminha no tempo: apropriações do poema "Martim Cererê" e o pensamento político de Cassiano Ricardo. Tese (Doutorado em História) - Faculdade de História, Universidade Federal de Goiás. Goiás, p. 368, 2015.

CRESPO, Regina. Cultura e política: José Vasconcelos e Alfonso Reyes no Brasil (1922-1938). Revista Brasileira de História. São Paulo, v. 23, nº 45, 2003, p. 187-208

EL-DINE, Lorenna Ribeiro Zem. Raça, história e política em Alfredo Ellis Jr. e Cassiano

Ricardo. 2010. 151 f. Dissertação (História) - Centro de Ciências Humanas e Naturais, Universidade Federal do Espírito Santo, Vitória, 2010.

FABRIS, Annateresa. O Futurismo Paulista: hipóteses para o Estudo da chegada da vanguarda ao Brasil. São Paulo: Perspectiva; Editora da Universidade de São Paulo, 1994.

$269 \mathrm{p}$.

FELL, Claude. José Vasconcelos, los años del Águila (1920-1925). México: UNAM,

2009. 737 p. Disponível em: <https://docs.google.com/file/d/0B9Ed9nf_plwQRWlzQ2J0YzVqZ2M/edit> Acessado em: 20/05/2018.

FERREIRA, Jerusa Pires. Notícias de Martim Cererê de Cassiano Ricardo. São Paulo: Quatro Artes Editora, 1970. 158 p.

GUELFI, Maria Lúcia Fernandes. Novíssima: estética e ideologia na década de vinte. São

Paulo: Instituto de Estudos Brasileiros, 1987. 264 p.

JARDIM, Eduardo. A brasilidade modernista. Sua dimensão filosófica. Rio de Janeiro: Puc-Rio, 2016. 144 p.

MONTEIRO, Amilton Maciel. Cassiano: fragmentos para uma biografia. São José dos Campos, SP: Univap, 2003. 424 p.

MOREIRA, Luiza Franco. Meninos, poetas e heróis: aspectos de Cassiano Ricardo do modernismo ao Estado Novo. São Paulo: Editora da Universidade de São Paulo, 2001. $195 \mathrm{p}$.

OLIVEIRA, Vera Lúcia de. Poesia, mito e história no Modernismo brasileiro. São Paulo:

Editora UNESP; Blumenau, SC: FURB, 2002. 342 p.

RICARDO, Cassiano. A Poesia dos cafezais. In. Correio Paulistano, LXIX, n. 23.283, p. 3, 3 de julho de 1928.

RICARDO, Cassiano. Martim Cererê e seus novos poemas. $4^{\text {a }}$ ed. São Paulo: Editora Novíssima, 1934. 178 p.

RICARDO, Cassiano. Martim Cererê ou o Brasil dos meninos, dos poetas e dos heróis. São Paulo: Editora Hélios, 1928. 116 p.

RICARDO, Cassiano. Martim Cererê. $3^{a}$ ed. São Paulo: Revista dos Tribunais, 1932. $139 \mathrm{p}$.

RICARDO, Cassiano. Martim Cererê. $5^{\text {a }}$ ed. São Paulo: Companhia Editora Nacional, 1936. 227 p.

RICARDO, Cassiano. Martim Cererê. São Paulo: Editora Hélios, 1927b. 163 p.

RICARDO, Cassiano. Minha terra tem palmeiras. In. Cassiano Ricardo, ano LXVIII, n. 22.800, p. 4, 11 de janeiro de 1927.

\section{GANPHLAC}


RICARDO, Cassiano. Nheengaçu verdeamarelista. In. Correio Paulistano, ano LXIII, n. 22.810, p. 2, 21 de janeiro de 1927.

RICARDO, Cassiano. O curupira e o carão. In. O curupira e o carão. São Paulo: Editora Hélios LTDA, 1927. p. 63-70

SALGADO, Plínio. A revolução da Anta. In. O curupira e o carão. São Paulo: Editora Hélios LTDA, 1927. p. 91-98

SALGADO, Plínio. Em defesa da Anta. In. Correio Paulistano, ano LXIII, n. 22.806, p.3, 17 de janeiro de1927.

SALGADO, Plínio. Formação nacional. In. Correio Paulistano, ano LXVIII, n. 22.926, p. 3, 19 de maio de 1927.

SALGADO, Plínio. Raça harmoniosa. In. Correio Paulistano, ano LXII, n. 22.708, p. 3, 10 de outubro de 1926.

SCHWARCZ, Lilia Moritz. O espetáculo das raças: cientistas, instituições e questão racial no Brasil - 1870-1930. São Paulo: Companhia das Letras, 1993. 287 p.

SCHWARCZ, Lilia Moritz. Nem preto nem branco, muito pelo contrário: cor e raça na sociabilidade brasileira. São Paulo: Claro Enigma, 2012. 148 p.

STEGAGNO ÍCCHIO, Luciana. História da literatura brasileira. Rio de Janeiro: Nova Aguilar, 2004. 744 p.

STEPAN, Nancy Leys. A hora da eugenia: raça, gênero e nação na América Latina. Rio de Janeiro: Editora Fiocruz, 2005. 224 p.

STERN, Alexandra. "Mestizofilia, biotipología y eugenesia en el México posrevolucionario: hacia una historia de la ciencia y el estado, 1920-1960". In: Relaciones. Estudios de historia y sociedad, vol. XXI, núm. 81, invierno, 2000, El Colegio de Michoacán, Zamora, México. Disponível em: <http://www.redalyc.org/articulo.oa?id=13708104> Acessado em: 20/05/2018

SUÁREZ Y LÓPEZ GUAZO, Laura. Eugenesia y racismo em México. Disponível em: $<\quad$ http://www.posgrado.unam.mx/publicaciones/ant_col-posg/29_Eugenesia.pdf >. Acessado em:15 de dezembro de 2017.

TELES, Gilberto Mendonça. Manifesto Nheengaçu verde amarelo. In. Vanguarda europeia e modernismo brasileiro: apresentação dos principais poemas, manifestos, prefácios e conferências vanguardistas, de 1857 até hoje. $5^{\text {a }}$ ed. Petrópolis-RJ: Vozes, 1978. p. 307-318

TENÓRIO, Mauricio. Um Cuauhtémoc carioca: comemorando o centenário da Independência do Brasil e a raça cósmica. Estudos Históricos. Rio de Janeiro, vol 7, n. 14. 1994 , p. $123-148$

VASCONCELOS, José. La raza cósmica: misión de la raza ibero-americana. Buenos Aires: Esparsa-Calpe Argentina S.A., 1948. 210 p.

VASCONCELOS, José. O Brasil apreciado por um estrangeiro. In. O Jornal, ano 5, n.1.439, p. 16, 16 de setembro de 1926.

VELLOSO, Mônica. História \& Modernismo. Belo Horizonte: Autêntica Editora, 2010. $128 \mathrm{p}$.

\section{GANPHLAC}

